\title{
ON THE USE OF SILVER AS MONEY IN THE UNITED STATES.
}

\section{INTRODUCTION.}

The history of monetary experiences cannot be too often considered. This consideration is particularly applicable at the present time to silver in its relation to American coin currency. Until quite recently silver has been but little used by the people of the United States as money. Indeed, it is still practically true that it is only used for change, as no large bills are issued on the silver reserve. Under existing law, however, the government is obliged to purchase an amount of silver nearly, if not quite, equal to the product of American mines. A new experiment is thus being tried, the result of which it is exceedingly difficult to predict with definiteness. An historical study is therefore timely.

The silver question, moreover, is "in politics." It has even come to occupy a most prominent position, and there has been developed not only a keen public interest in the philosophy of the bimetallic controversy, of which the silver question in the United States is but a phase, but a strong desire for accurate knowledge regarding the history of our currency.

The free coinage party are practically urging still another experiment. In considering it and the future currency policy of the country, and of the world, too frequent reference cannot be made to the results of the several experiments in currency legislation which former Congresses have undertaken. History may afford some light to guide us in selecting or in avoiding certain courses of action.

The subject has been treated by many writers in recent 
times, either in special treatises, $*$ or in the systematic text-books on political economy, particularly those by Andrews, Ely, and Walker. Three international conferences have been held in the vain hope of securing concerted action by the principal commercial nations. The question has been made the subject of investigation by Congressional and by Royal Commission. Yet, in spite of books and reports, of investigations, prize contests, and the rest, widespread ignorance remains regarding the prominent and fundamentally important facts in the history of the use made of silver as money by the people of the United States; the laws which have been passed; the conditions which gave rise to these statutes; and the effect of the various enactments on the circulation of coin throughout the community.

Materials for original study are to be found in the statutes themselves and in the reports of the Congressional debates connected with their enactment, in reports to Congress, in petitions, and in current financial literature. The reports of the Silver Commission of 1876 and of the International Monetary Conferences of 1867,1878 , and 1881 are replete alike with information and with argument concerning the relative merits of gold and silver for use either separately or conjointly as money. Abstract discussion of the advantages or the dangers of "bimetallism" is not attempted here: it is the aim of the writer to show the actual use made of silver as money during the century, by the people of the United States, and to explain the reasons for that use, in the hope of correcting false ideas and disseminating a knowledge of the necessary conditions of bimetallism.

* Sumner, "History of A merican Currency" (1874); Cernuschi, "Nomisma, or Legal Tender" (I877); Linderman, "Money and Legal Tender in the United States" (1877) Weston, "The Silver Question" (1878); Walker, "Money" (1878), and "Money, Trade and Industry" (1879) ; Bolles, "Financial History of the United States," 3 vols. (1879-1886) ; Knox, "United States Notes" ( $\left.188_{4}\right)$ (third edition 1888) ; Upton, "Money in Politics" (1884); Laughlin, "History of Bimetallism in the United States" (1886) ; Nicholson, "Money and Monetary Problenus" (1888); S. Dana Horton, "Silver in Europe" (I8go); Boissevain, "The Monetary Question" (I89x); Cowperthwait, "Money, Silver and Finance" (1892); Ehrich, "The Silver Question" (r892); Taussig, "The Silver Situation in the United States" (1892). 


\section{EARLY HISTORY OF THE MINT.}

In 1783 Robert Morris presented to the "United States, in Congress Assembled," a specimen American coin. Our national coinage may be said to date from the making of this coin.

For several years the matter had been under discussion and had been made the subject of special reports ; but Congress repeatedly postponed definite action. The report of a special committee created in 1784 , of which Jefferson was a member, outlined a plan, based on the report of the Superintendent of Finance. On July 6, 1785, and August 8, I786, more definite regulations were made in anticipation of the creation of a national currency, and finally, on October I6, I786, there was enacted "An Ordinance for the establishment of the Mint of the United States of America and for regulating the value and alloy of coin," and provision was made for the employment of proper officers and workmen in the Mint. This plan, however, was never carried into execution, as matters of greater importance occupied the government and the people of the United States. It was not until after the adoption of the Constitution that the Mint was established, and it was practically a generation and a half before a national coin currency came into general use.

In the practical administration of affairs it is often an imperative necessity that, with or without the aid of legislation, the kind of money to be received by the government in payment of taxes, dues, etc., shall be determined. When income does not equal expenditure, it becomes necessary for a government to borrow money. During the Revolutionary War the Congress of the United States had authorized the executive officers to borrow dollars. But what is a "dollar?" No one is disposed to ask this question when the currents of industry, trade and commerce are flowing smoothly. It is only in periods of sudden change and uncertain credit, or of legislative interference with the representative of the money of account, that doubt arises. In the years following the 
adoption of the Constitution the matter became one of serious difficulty, requiring for its resolution the careful and disinterested consideration of the statesmen of the period.

In a certain sense it is entirely in the power of Congress to determine what shall be considered a dollar-what shall be the monetary unit of the country. Every industrially developed community must have a money of account. It is at once the evidence and the basis of commercial progress. It is the condition of trade on a large scale. But the political power in the State, the statutory law, determines what shall be the material representative and coin equivalent of the unit of account, as well as what shall be legal tender in payment promises of to pay money and in settlement of obligations. By the Constitution of the United States (Article I., Section Io) the States are forbidden to " coin money; emit bills of credit ; make anything but gold and silver coin a tender in payment of debts." And by Article I., Section 8, clause 5, Congress is given power "to coin money, regulate the value thereof, and of foreign coin, and fix the standard of weights and measures." This power Congress has repeatedly exercised.

When, under the Articles of the Confederation, Congress instructed the Superintendent of Finance to report a table of rates at which the different species of foreign coins, most likely to circulate within the United States, should be received at the Treasury, Morris insisted, by way of reply, that "In the present moment [ 1782 ] it is by no means of such consequence to establish the relative value of different coins, as to provide a standard of our own by which in future to estimate them." His report* was devoted to an exposition of the dangers and disadvantages threatening the existing currency and to the presentation of a plan for improving it. He argued that a uniform currency was necessary to industrial security and development. Coins of every description-Spanish and English coins, coins of France and coins of Portugal-coins of various values and

* Diplomatic Correspondence, Vol. XII., p. 8I 
of varying value-all were current in different parts of the country. The pound was the money of account, but most diverse ideas prevailed regarding pounds, shillings, and pence. The want of small coin for the common occasions of trade; the need of a legal tender to protect both the honest debtor and the honest creditor ; the disappearance of the depreciated medium, the Continental currency, with its infinite inconvenience and danger ;--all argued the wisdom of adopting an American coinage system and of establishing a government mint. The time appeared opportune. There was a sufficient supply of specie in the country : it needed only to be recoined into American coins, and this could be done in a very short time. Above all, the public credit, which was almost completely broken, would be greatly strengthened. In the mind of the Superintendent, or of his Assistant, Gouverneur Morris, who is probably the author of the report, in the main, the opportunity imposed the duty. Still, for a decade, Congress took no action.

The conclusive argument, the compelling cause, which finally brought partial order out of monetary chaos, was indicated by Hamilton in his report on the "Establishment of a Mint," January 28, r79r. "The dollar originally contemplated in the money transactions of thiscountry," says the report, " by successive diminutions of its weight and fineness, has sustained a depreciation of five per cent. . . . The value of property . . . fluctuates with the fluctuations of a foreign mint." Manifestly there was neither security, convenience, nor economy in dependence upon a foreign mint. Depreciation and debasement of our money by acts of a distant sovereign were not to be tolerated. The Second Congress, by the Act of 1792 , attempted to provide the means for securing a uniform, convenient, and intelligible system of national coins.

Perhaps the most important feature of the act establishing the mint was the provision authorizing the free coinage of both gold and silver. Both metals were to be coined gratuitously 
for all comers, in the order of arrival. The legal step tending toward bimetallism was taken in this first act regulating the currency. The silver dollar or unit was " to be of the value of a Spanish milled dollar" as the same was then current, "and to contain," continues the statute, "three hundred and seventy-one grains and four-sixteenths parts of a grain of pure, or four hundred and sixteen grains of standard silver."* This unit for silver coins was not that proposed by Morris-one-quarter of a grain of pure silver, with 1440 to the dollar-which Jefferson had characterized as too minute for ordinary use and too laborious for computation. It was not the unit urged by Jefferson himself, who desired a single unit both for weight and for money. It was not entirely the dollar suggested by Hamilton. The pure metal contained, $37 \mathrm{I} / 4$ grains, was in accordance with his proposition, and it is interesting, though perhaps not important, to note that no change has since been made in the weight of pure metal in silver dollars except for the small number of trade-dollars coined in the seventies. The gross weight, 416 grains, was that of an average lot of Spanish coins bearing the date ${ }^{7} 6 \mathrm{r}$, but then no longer current.

The principles and proposals of Hamilton concerning gold coins were adopted entire. The gold coins were spoken of as units or dollars. "A preference," he says, "ought to be given to neither of the metals, gold or silver." $\mathrm{He}$ was of the opinion that the money unit had virtually been gold rather than silver, silver dollars having circulated by tale as a mere money of convenience, without much regard to either weight or fineness; but he presented what seemed to him strong reasons for endeavoring to make permanent the concurrent circulation of both kinds of money. Both alike were required for home and for foreign trade.

* This most peculiar proportion was not actually adopted by the mint authorities until 1796 , after Congress had repeatedly refused to modify it, and the Director of the Mint was unwilling longer to disobey the statute. Why this inconvenient standard, 1485 , was first adopted and then forced on the mint, it now seems impossible to determine. 
"If gold be most convenient," he said, " in large payments, silver is best adapted to the more minute and ordinary circulation. . . . To annul the use of either of the metals as money is to abridge the quantity of circulating medium, and is liable to all the objections which arise from a comparison of the benefits of a full, with the evils of a scanty, circulation."

Hamilton was a practical bimetallist. He aimed to secure the concurrent circulation of the two metals for commercial convenience. To-day "free coinage" is demanded on the score of justice as between debtor and creditor. The concurrent circulation of the two kinds of coins proposed is at least a matter of doubt; it might or it might not result, by raising the price of silver to $\$ 1.29$ per ounce, as is predicted.

Bimetallism is to be defined either as a state of the law or a state of the currency. If the latter is accepted as the most satisfactory definition of the term, the state of the law must be regarded as merely the means to the end, and practical bimetallists-those who seek the end-may and will differ as to the law which will prove most efficacious under any existing circumstances. Mr. Bland asserts, and some, perhaps all, of the men who act with him honestly believe, that concurrent circulation would result from a law allowing the free coinage of both metals at the old ratio of 16 to $I$. Hamilton, a century since, in considering the state of the currency, believed that the two kinds of coins would circulate only if made at the ratio of $I_{5}$ to $\mathrm{I}$. He fully appreciated the difficulties of successfully carrying out the policy of bimetallism, and the necessary consequence which would follow any considerable underrating of either metal- "banishment of that which is undervalued; . . . diminution of the total quantity of specie which a country would naturally possess; . . . greater and more frequent disturbance of the state of the money unit." He therefore urged that care be taken to regulate the proportion of pure metal in the two varieties of coin, "with an eye to their average commercial value." 
Hamilton, placing this market ratio at very near $x_{5}$ to $I$, and believing that this ratio would be permanent, proposed (I) gold coins, with $243 / 4$ grains, and (2) silver coins, with $37 \mathrm{x} / 4$ grains of pure metal to the dollar, -

"The alloy in each case to be one-twelfth of the total weight, which will make the unit 27 grains of standard gold, and 405 grains of standard silver. The former," he continues, "is exactly agreeable to the present value of gold, and the latter is within a small fraction of the mean of the two last emissions of [Spanish] dollars-the only ones which are now found in common circulation."

The questions before Congress, as enumerated by Hamilton in this report, were the following :

I. As to the nature of the money unit

2. As to the proportion between gold and silver, if coins of both metals were to be established

3. The amount and composition of the alloy

4. The amount of seigniorage

5. The number, denomination, sizes and devices of the coins

6. The currency of foreign coins.

The answer which Hamilton gave to the first and second of these questions was simply, That the law should recognize and endeavor to make permanent the conditions of the currency existing at the time so far as the unit and the concurrent circulation of both gold and silver coins were concerned, and should establish and preserve a standard dollar by the substitution of national coins for a miscellaneous lot of semiinternational coins with constantly changing values.

These principles were practically those presented by Jefferson in his letter of 1784 . In the time intervening after that report was written Jefferson had studied with care the practical features of the art of coining as practiced in Europe, and had acquainted himself with workers in metal and the possibilities of securing officials for the Mint. When the Mint was established, in I792, it was placed under his charge in the Department of State. We may conclude 
then that, while the outline of our system of currency was determined by the conditions of colonial trade, its distinguishing characteristics may be ascribed in about equal measure to the influence of these three men-Morris, Jefferson and Hanilton.

In the discussion regarding the Mint and the currency during this early period one seeks in vain for any evidence of a bimetallic controversy like that of recent times. As a state of the currency in every way desirable and convenient, bimetallism was an acknowledged fact. It was accepted not only as practicable but necessary, and the law which laid the foundation of our national coinage system was conceived for the purpose of providing the legal conditions necessary to its continuance. It had been, and for a long time it continued to be, an open question whether the expenditure necessary for the establishment of a government mint would be a good investment. But when it was determined to undertake this work discussion seems to have become limited to the purely practical considerations of convenience in the coins. Indeed, little more interest was manifested in the subject, at the time, than during the days of the Continental Congress. Though the bill was before the Senate several times between December $2 \mathrm{I}$ and January 9, the only reference to it in the Annals of Congress regards the employment of officers, the keeping of accounts, and the emblems to be borne by the coins. The latter subject occasioned an interesting and an amusing discussion in the House, and even resulted in a difference between the two Houses. The Senate had proposed a representation of the head of the President for the time being, with his name, etc., but it was objected that to do this was to incur the danger "of imitating the flattery and almost idolatrous practices of monarchies." Despite the popular ridicule of the idea of "the people's being enslaved by their President, and much less by his image on their coin," the House of Representatives, by a vote of 24 to 32 , refused to recede from its amendment in 
favor of a design "Emblematic of Liberty." The Senate ultimately accepted the amendment, but the character of the emblem was left entirely to the discretion of the administration.

April 2, I792, the Act was approved by President Washington, who had been authorized the year previous to engage artists and procure apparatus, and the work of minting began at once. But the making of coin was a new industry in this country. The initial difficulties to be overcome were many and great. Workmen were to be obtained, and the plant, and the raw material furnished; suitable buildings, furnaces, delicate machinery, dies, rollers, presses, drawing and milling machines were wanted; and both materials and tools were lacking, and machinists and skilled workmen were not easily found. Finally, when the Mint was ready for work, there was little work to be done. Coin and bullion were sent in small quantities only, and the treasury did not provide means for the purchase of bullion. The exper.se of refining, much greater then than now, was at first borne entirely by the government. Again there were no laws which properly protected the government in the monopoly of coinage. In the report for 1795 , the Director of the Mint states that mints were erected at Baltimore and elsewhere, professedly to imitate the coins of foreign countries and to furnish a debased gold coin for the West India market. How much minting they did is not stated.

The minor and technical difficulties relating to methods of manufacture and management were gradually overcome, partly with, partly without, the aid of legislation. But the major difficulty remained: neither coin nor bullion was offered at the mint with any regularity or in sufficient quantities* to employ the mint officials or to affect appreciably the coin currency of the country. This lack of material was at once a cause and an effect of the difficulties

* See American State Papers, Finance, I., pp. 476 and 504. 
encountered. Neither gold nor silver was produced in the country ; no private interest existed anxious to avail itself of the privilege of having its product gratuitously manufactured by the government; neither was there any inducement for individuals to offer foreign money for recoinage while the foreign coins were convenient and were full legal tender.

Worst of all, the treasury entirely failed to co-operate with the mint in the effort to provide a system of national coins. Even after inquiry on the part of a House Committee, the secretaries refused compliance with a very definite provision of the statute, according to which all coin received by the government officials in the treasury department was to be sent to the mint and recoined into American money before being allowed to pass into circulation again. It is true that the governmental transactions of receipt and in many instances expenditure of moneys took place at distant points. The officials in charge apparently deemed it unwise to entail the expense of transportation in both directions. Even the money received in Philadelphia was not sent to the mint. As late as 1803 , the Director of the Mint reports that no precious metal had been coined on account of the Government of the United States.

Hamilton had considered three years an ample time for the conversion of the coin currency of the country. The average annual net "ordinary" receipts of the government from 1796 to I 800 were over $\$ 8,000,000$-an amount certainly equal to one-haif the total amount of coin in the country at the time. That the conversion of the coin was possible within three years is conclusively shown by these figures; still the average annual coinage at the mint for the decade 1795-1805 was only $\$ 500,000$. If the treasury department, which had recommended it, would not conform to the law seeking to substitute a national for a foreign coin, it was not to be expected that individuals would do so, or would voluntarily undertake the task. 
The few coins that were made were soon exported. The cheaper coins-those invariably chosen when preference is offered-were the worn and depreciated foreign coins. New American coins could not "drive them out." English, French, Spanish and Portuguese coins circulated freely, and from time to time certain of them were made legal tender, at specified rates, by tale or weight. The American dollars and eagles were exported, because worth more as commodities in other markets than as a circulating medium or a means of paying debts in the United States. Gold coins were not issued until the latter part of $I 795$, and as early as I 798 it was stated in Congress that a large quantity had been seen in a goldsmith's window in England. "Thus easily do our eagles take their flight." *

In the first years of the century the drain of silver dollars was so great that the government ceased making them after March, 1804 , none being issued thereafter until I 836 . It is worthy of note that this policy was originally adopted by the administration as a means of preventing the exportation of coins, and was followed by the mint authorities without any specific law authorizing them to refuse to coin silver dollars.

During all this time the mint occupied a precarious position; even its continuance became a matter of dispute. By many it was regarded as an expensive luxury, a needless burden, which ought not to be borne longer. It was urged that it cost $\$ 1.00$ to coin $\$ 10.00$. In 1802 a bill to close the mint passed the House, but failed in the Senate. After extended discussions, the acts were passed providing for the continuance of the mint at Philadelphia for a period of from one to five years. It was not until i 828 that the bill passed Congress providing for its permanent establishment. In 1782 , in the report of the superintendent of finance, it was urged that the coins put into circulation should be few and simple, in order that they might "become familiar to

\footnotetext{
" "Annals of Congress," 5th Cong., Vol. I., p. 750 .
} 
all ranks and degrees of men." Nearly two generations passed away before the first American coins, the very coins -of gold-which Morris had held we should never need, became thus familiar to the people; and the third generation was well advanced before a general national coin currency was secured by the subsidiary coinage law of 1853 and the laws of 1864,1865 and 1866 authorizing the smaller token coins.

Bank-notes were more successful in the competition with foreign coins. After 1800 the bank circulation became an important factor in the currency of the country. Prior to that time the currency of the country was composed almost entirely of gold and silver money. Subsequently banks came into existence in rapid succession. The Bank of the United States (179I-181 I) afforded a reasonably satisfactory credit currency; but its dissolution in I8I occasioned an enormous increase in the credit currency of the country. In 1815 the domestic paper which the treasury felt obliged to receive was of every degree of unsoundness. Specie payments had been generally suspended in I8I4. The latter part of the war had been conducted almost entirely on treasury notes instead of long loans and bonds. In his report of December 6, I815, Dallas stated that it was impossible to estimate the working value of the income of the government. "The possession of funds in one part no longer affords evidence of a fiscal capacity to discharge a public debt in another part of the Union." The differing values of the foreign coins used established at least seven different standards of value in the current money. The situation was as serious as in the days before the adoption of the Constitution.

The period from 1815 to the panic of I8Ig was one marked by extreme fluctuations, prices and credits changing with war-time rapidity. There were no uniform and convenient instruments of credit; no medium existed for circulating obligations and facilitating transfers of the 
evidences of debt; no money of constant value was circulated throughout the length and breadth of the land; there was no secure basis for any portion of the vast amount of credit currency ; no standard or "common denominator" of value. All things were measured in the primitive unita day's labor. Net imports rose and fell as follows, in millions of dollars: I8I4, 12.8; I815, 106.5; I816, I30; I $817,79.9 ;$ I $818,102.3 ; 1819,68$. The net ordinary receipts of the government were 15.7 million dollars in $1815,47.7$ in I8I6, 33 millions in $1817,21.6$ in 1818 , and $\$ 24,600,000$ in I819. Exchange on London, which had fallen to twenty per cent discount on the nominal par $\left(\$ 4.44 \frac{4}{9}\right)$ in 1812 , was twenty per cent premium in 1816 . The depreciation of the paper currency was an important element in the situation, and a direct cause of the deranged state of industry and commerce.

The evil effects of unsound currency and the necessity for a mint and a national system of coinage were felt even more strongly after the panic of 1819 and the resumption of specie payments by the Bank of England after a suspension of twenty-six years. As between individuals, it is contrast with others that develops economic wants among nations. In international intercourse, trade and competition, it makes but little difference how poor the currency of a country may be, and indeed its deficiencies are not realized, until other nations secure a money of a higher industrial grade. In 1814 a deranged currency and the suspension of specie payments operated as an expelling force. In 18 I 9 organization and system abroad, the resumption of specie payment in the English currency, added an impulse attracting the better part of our currency to other countries.

As a means of relief from currency difficulties Congress chartered the (Second) Bank of the United States in I816, with right to establish branches and with privileges of issue, and revived for three years an act making certain foreign coins legal tender. Again a bank-note circulation, with 
foreign coins as a basis, was accepted as our national currency. This secured neither soundness for the credit currency of large transactions, nor convenient fractional money for retail trade.

In his report on the banks and the currency in 1820 , the Secretary of the Treasury, Crawford, stated that small notes circulated in a majority of the States to the exclusion of silver. Small change was not abundant anywhere except in Philadelphia, the seat of the mint. Tickets of $61 / 4$, IO, 12 1/2, 25 and 50 cents, issued by mayors and corporation officers, and dollar bills torn in two pieces for the purposes of change, were everywhere used. "The fractional parts of a dollar," he said, "are so indispensable in the transactions of individuals that anything which assumes that character will be employed." **

Two other plans were proposed in 1816 and I8I9 for securing a better currency, but neither was adopted. First it was proposed to prohibit the exportation of coin ; for the new coins were regularly exported, particularly to India. Both the Secretary of the Treasury and the Senate Committee reported against the bill proposing the old remedy of a prohibition on the exportation. Such a law, they claimed, could not possibly be made effectual in any country, least of all in the United States; and so far as it was actually operative it would be in favor of the more corrupt and dishonest portion of the business community. Congress did not commit the folly of enacting this law : the testimony of history to the inefficiency of the means was too great. Neither did it then adopt the second plan proposed-that of reducing the weight of the monetary unit and thus making a given amount of metal in the shape of an American coin worth more in domestic trade and for the payment of debts at home than for export. This plan had been strongly urged in I 816 , and was favorably reported on by a House Committee in $18 \mathrm{I} 9$. In the latter instance it was recommended

\footnotetext{
* Report of February 12, 1820. American State Papers, Finance, III., p. 494.
} 
that a charge of 14.85 grains be made for seigniorage on fractional silver coins, their legal tender quality being limited to the payment of debts of five (5) dollars or less, and that the weight of the gold coins be reduced about four per cent.

By this.time gold had disappeared entirely from circulation and even in goodly measure from the vaults of the banks. Their reserve was largely fractional silver. Foreign coins circulated in seaport towns and on the frontiers, where bank paper was not received. But again, the only action taken by Congress in 1819 , was to extend the life of the mint for another period of five years, and to continue the legal tender quality of certain foreign coins-Spanish coins indefinitely and French silver coins for four years.

The amount of gold and silver coins issued by the mint of the United States in each quinquennial period, from 1792 to $\mathrm{I} 834$, is as follows, in millions of dollars :

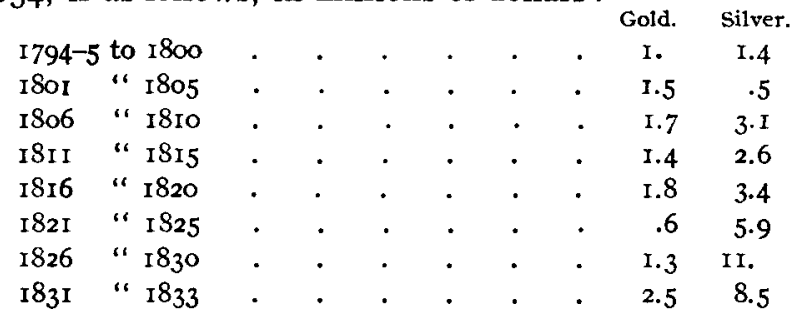

This period has been called the silver period by the historian of bimetallism in the United States. ${ }^{*}$ It is much more distinctively the period of bank notes and of foreign coins. Indeed it can hardly be said to have been a period of American coinage. In describing it, Professor McMaster says : $\dagger$

"The coinage, though national in name, was not national in value. The old stockings of the people were full of coins bearing the stamps of many foreign mints, called by all manner of names, and possessing different values in different places. . . . They had been in circulation long before the war for independence, had seen much service,

* Professor J. Laurence Laughlin, of Chicago University.

+ "History of the People of the Uuited States," Vol. I., p. I89. 
and were none the better for the wear and tear they had sustained. The four pence pieces passed for six and a quarter cents if the inscription was legible, but only for five if smooth and 'crossed.' The nine pence passed for twelve and a half cents. The pistareen was worth twenty cents. The picayune went for six and a quarter cents. . . . Some shilling pieces and six pence pieces were to be found in circulation down even to the Civil War, and were, with the fips, the levies and the pistareens, the last relics of a time happily passed away."

\section{THE GOLD COIN BILI, OF I834.}

The first important change in the laws relating to our coinage system was made in 1834 . Its purpose, according to the advocates of the measure, was to resuscitate the gold currency. The administration had been successful in its prolonged contest with the bank. This fact, together with the increasing importance of gold mining in the Southern States, seems to have been the direct occasion of the law and to have determined its character. It was approved by President Jackson on June 28 . By it the weight of the gold coins thereafter issued was to be about six and a quarter per cent less than under the law of I792. This, says Mr. Laughlin, * debased the gold coins of the United States 6.26 per cent, and to that extent the law gave gold a less legaltender value than it had possessed before 1834 . (The italics are my own.)

But is this debasement? It would seem rather to be a provision for the manufacture of another kind of commodity. Debasement of a coin implies its being called in by the government, in a more or less despotic manner, and the enforced substitution of one of less value. It is a depreciation of the monetary unit under forms of law, an arbitrary political attempt to get something for nothing. In the present instance, however, there were very few coins which could be called in, nine-tenths of all those issued having been exported or melted, and provision was made in the law for rating such as still existed and were presented at the Mint

* History of Bimetallism in the United states," p. 7o. 
in proportion to the pure metal they contained. Before 1834 an amount of gold worth 103 or 104 cents had been legal tender for $\$ \mathrm{I}$. But certainly this was not a very valuable privilege of which owners of gold were deprived. The old gold coins had not served as money in America for twenty years and more.

But it was now desired for two reasons to secure a gold currency. For twenty years the currency question had been under discussion. It had been made the subject of special investigations by, and lengthy reports to, Congress. Secretaries of the Treasury, notably Crawford in 1820 and Ingham in $183^{\circ}$, had vied with Chairmen of Congressional Committees -Lowndes in 1819, Sanford in 1830 , and C. P. White in several reports from $\mathrm{I} 83 \mathrm{I}$ to $\mathrm{I} 834$; -secretaries had vied with chairmen, in preparing extended treatises on the nature and character of currency and in devising plans for improving the condition of American currency. But Congress paid little heed to reports and petitions. The paper currency of the country and foreign silver coin continued to serve as the money of the community. It was in the interest of those who supplied the former to maintain as strong a demand and as complete a monopoly as possible. The Secretary of the Treasury said in a letter to the Committee of Ways and Means that the great evil of the currency was the disproportion between the paper in circulation and the coin prepared to redeem it, and urged that the first step toward a sound currency was to reform the coinage of gold.* Only a gold currency, it was claimed, could compete with, or form a proper basis for, a paper currency. The fancied special interest of a particular class, the owners of gold mines, added the impulse needed to secure legislation.

Some sort of currency a community must have. Industrial and commercial needs compel its creation. The law only regulates it or invites the creation of a particular kind. The general public accept foreign coins and a voluminous

* Quoted in the Debates in Congress, Vol. X., p. 4644 . 
paper currency based on them, despite the disadvantages and dangers, until a stronger interest is enlisted in supplying a better currency. The first requisite of the currency for.ordinary transactions is that it be simple, convenient and uniform. A great variety of bank-notes and of foreign coins, of different values in different portions of the trading community, cannot constitute a good currency. The first improvement to seek is uniformity, and thus familiarity. Fips and tuppenny bits will circulate till worn smooth as glass, and paper dollars until badly torn, patched and dirty, simply because they are familiarly known. It had been expected that the Bank would secure the desired end. But in his first message to Congress, in December, 1829, Jackson stated that the bank had entirely failed in the effort to establish a uniform and sound currency. Certainly this statement, and the subsequent policy of the administration in the contest with the bank, was not calculated to secure to the currency either uniformity or soundness. There was thus apparently another reason for currency legislation.

In the early period the question had been, Shall we have American coins? The issue was entirely between the acceptance of the system of foreign coins left over from colonial days and the substitution of domestic or home-made, national, coins. The foreign coins and a paper currency won the day. The question now was, Shall we have coin or paper, hard or soft money? The practical question before Congress concerned the legal restrictions and regulations necessary to secure the chief requisite of a credit currency-soundness. The great desideratum in money is stability. That the dollar, the monetary unit, should be invariable becomes increasingly important as the use of credit instruments is extended. A measure, or standard, cannot be good if variable.

In 1834 the basis of our credit currency was made up of foreign coins and the fractional silver coins. Foreign gold coins had ceased to be legal tender in 1819 . Little gold of 
any kind, native or foreign, remained in circulation after 1820. The silver coins were old and worn. The larger part were Spanish-the only foreign coins which were legal tender from 1827 to 1834 . They had been in circulation from twenty to one hundred years. The bulk of the currency was paper-the notes of a great number of banks. These banks were of every degree of solvency, but the government received their notes until the issuance of the famous specie circular in 1836 . American coins were few. The old Spanish coins were the nearest existing approximation to a standard of value. The currency was neither uniform, convenient nor simple, and it was maintained that this coinage system was allowed to continue in order to promote the use of bank-paper and preserve the unsatisfactory condition of the currency in the interest of gamblers and dishonest speculators.

A new mint had been built in 1831 , and a bill to revise the coinage system passed in the Senate. From the standpoint of the government, there was evident folly in maintaining this mint in the comparative idleness entailed by the law as it then existed, or in using it to manufacture gold and silver for export. The capacity of the mint was double, possibly treble, the amount issued in the years immediately preceding 1834 . It was used, moreover, as it was again later when the quantity of gold greatly increased, simply as an inexpensive means of getting metal into a convenient form for exportation. It was clear that the coinage of gold should be entirely abandoned, or means provided for securing the circulation at home of the coins which were made at government expense. Gold had never been an important factor in our currency. The premium in New York from I 827 to I 834 was from three to ten per cent. To retain the gold coin and make it the chief component of our currency, it must be made so as not to be more expensive than the silver coin, and together with silver it must also meet the conditions of competition with paper. To accomplish these 
ends was the avowed purpose of the supporters of the Gold Coin Bill of 1834 .

On March 29, I834, Benton introduced in the Senate a resolution for a joint committee to report what alterations, if any, were necessary to be made :-

First, in the value of the gold coined at the mint, "so as to check the exportation of that coin, and to restore it to circulation."

Second, "in the laws relative to foreign coins, so as to restore the gold and silver coins of foreign nations to their former circulation within the United States."

Third, in the regulations for the collection of the revenue, with a view to making the revenue system instrumental in " the introduction of gold and silver for the common currency of the country."

From this presentation of the subject it would appear that the ultimate object and the practical difficulties were the same in $\mathrm{I} 834$ that they had been in I792. Little, if anything, had been accomplished in the effort to provide the country with a sound and uniform currency. The important questions as to the nature of the money-unit and the proper legal ratio between the two kinds of coin were still unanswered.

As finally passed, the law made no change in the silver coins, but reduced the weight of the gold eagle to 232 grains of pure metal, thereby raising the ratio to a trifle over 16 to $\mathrm{I}-37 \mathrm{I} \frac{1}{4}$ to $23 \frac{1}{5}$, or 16.002 . This ratio had been proposed by Secretary Crawford ten years earlier. Mr. Lowndes had recommended 15.6 to 1 in 1819 , though the Director of the Mint had at that time reported the ratio of I 6 to $I$ as the market rate prevailing in some parts of Europe. A select ccmmittee of the Senate, in I830, had proposed 15.9 to I, a mean between different legal rates established by the various countries of Europe and the commercial rate prevailing in South America-the country whence came our supply of silver. These various recommendations would indicate honest differences of opinion. 
The market rate is a matter of fact; but a matter of fact difficult to determine with accuracy. As now stated in the report of the Director of the Mint, the average rate for the year I 833 was 15.93 . In 1808,1812 , and 1813 it was above 16, and prior to 1834 it was frequently above 15.8 . Mr. Jones, of Georgia, insisted in debate that the divergence of the proposed legal rate from the existing market rate was only $3 / 4$ of one per cent, and he justified the mint rate of 16 to $I$ on the ground of a probable further advance in the ratio. Mr. Gorham replied that the rate here was 15.63 ; that in France it was 15.68, and in England 15.77 . He consequently maintained that the contemplated regulation concerning gold coins would add two and one-half per cent to the value of gold coins. Assuming the correctness of his figures this makes evident not only the impossibility of bimetallism under the new law, but the fact that in passing it Congress would be responsible for a perceptible lowering of the standard of value- " the greatest wrong charged against the tyrants of the Middle Ages, and one which no modern despot has dared to repeat."*

From these statements made in debate, it would appear that a bimetallic controversy took place in the Twenty-third Congress. Stronger interests had developed on each side. Monometallism (of silver money) was the acknowledged fact in our coin currency. The standard of value, in so far as there was one, was in silver, though it must remain a matter of doubt whether the standard was the ideal unit of two half dollars, which contained 37 I $/ 4$ grains, or the worn Spanish coins, which when issued contained, some of them, 365 , and others 374 , grains to the dollar. Silver monometallism was not, however, so generally accepted in 1830 , as the permanent policy of the country, as bimetallism had been

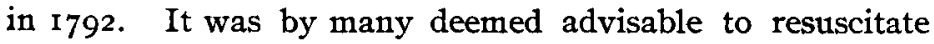
the gold currency. If this was to be attempted, the practical question of ratio would become the point of issue.

\footnotetext{
* Sumner, "History of American Currency," p. III.
} 
Should it be less than, equal to, or greater than the commercial rate? And what was the real commercial rate? The (silver) monometallists who were anxious to preserve the standard unchanged, and fearful lest gold should be overvalued in the coins, and thus the standard be lowered, sought to place the mint rate lower than the market rate, and insisted on the ratio of 15.625 to $I$ as the highest which could safely be adopted. In the House this was voted too low, the vote standing 52 to 127 . Bimetallists-those who desired joint circulation of both kinds of coins, the gold for the large, the silver for the small, transactions-urged that the mint rate for gold might be slightly higher than the market rate. Silver being a heavier metal and the coin larger, it would circulate in retail trade though undervalued. The ratio of 16 to $I$ was approved in the House by a vote of 145 to 36 , the compromise rate of 15.865 having been voted down-69 to II 2 .

It would thus appear that an honest difference of opinion existed both as to what was the commercial value of gold in terms of silver and as to how far the legal rate could practically diverge therefrom, under the circumstances then existing, without expelling silver or gold from circulation. The metal market was not active and settled. The original unit had not been exactly defined, and the ratio formerly adopted, I5 to I, was founded on information which was more or less vague and incorrect. The conditions had not greatly changed in 1834 . The situation is made difficilt, and the making of any dogmatic statement as to the intention of the law-makers is prevented by the impossibility of ascertaining the facts regarding the market price of metals. The result is not clearly proved. Certainly, no active business could be conducted in buying up dollars which had not been coined.* It seems doubtful whether the standard was appreciably reduced, even through the psychological influence of the new statute. Neither the movement of the

* Andrews, "Institutes of Economics," p. 204. 
coin nor the change in the standard of value in the community would appear to have been automatic to the degree implied by the statements of extreme monometallists.

While the injustice of actual debasement is unquestionable, a doubt may be fairly entertained as to the fact in any particular instance. The commercial rate varied from year to year* and was different in the different markets with which we had direct commercial intercourse ; 6 to I appears to have been the average market rate. The excess of imports over exports of coin and bullion for the years 1834 to 1839 was: gold, $\$ 23,542,326.00$; silver, $\$ 26,801,954.00$. In the years I 834 to I842 silver was coined to the value of $\$ 22,295,339.60$, while only $\$ 19,207,810$ worth of gold was coined. It is at least doubtful what actually constituted the standard of value in the minds of the people in 1834-the American coins not in use, the paper currency, or the current Spanish coins of which the value as silver was so various. That the experiment cost every creditor two and a half cents on every dollar, as Mr. Sumner states, is hardly to be believed, in the light of the above figures taken in connection with the mania for bank circulation and the enormous speculation of the years 1835,1836 and 1837 .

It is true the ratio adopted proved too high. Silver did not fall so low again until $1874^{*}$ But how far its adoption was due to an error of judgment on the part of sincere bimetallists and how far to the desire to "encourage and protect" gold mining in the Southern States, or how far it resulted from a dishonest intent to indirectly scale down debts by lowering the value of the monetary unit, cannot be determined. Consideration of the political situation leads to the inference that it was the intention of the majority of those in power to overrate gold slightly. The desire of the administration party to secure a specie circulation was presumably a prevailing force in the minds of many. Gold coins were necessary to the success of their plan. To gold coin

\footnotetext{
* See Diagrams IV. and v.
} 
should consequently be given the benefit of any doubt. It was desired also to extend the market for gold. Small amounts had been coming to the mint from North Carolina ever since 1804 . In 1824 one-fifth and in 1826 one-fourth of the total amount coined was "native." In 1832 there came to the mint from the Southern Alleghanies $\$ 678$, 000 value in gold, and in $1833, \$ 868$, 000 .*

As early as I829 a committee had been appointed to consider the advisability of establishing a branch mint in North Carolina. One was organized in 1838 . The gold-mining interests called for congressional action to provide a market for gold, and thus raise its price. Finally, a few votes or parts of votes came from the political influence of those who were in pecuniary difficulties, and were seeking legislative relief.

But the charge of sinister motives is based quite as properly on the manner in which the act was passed as upon the speculations on its possible, or knowledge of its actual, effects. The bill which had been under discussion during the session, and been passed in committee of the whole, proposed a ratio of 15.625 to $I$, and the fractional parts alike of the eagle and the dollar were to be depreciated from three to five per cent of the standard weight and to be made legal tender for $\$ 10.00$ only. This bill was dropped at the close of the session and an entirely new one substitutedone differing in principle and establishing the 16 to $\mathrm{I}$ ratio. This was discussed in a somewhat slimly attended House only a week before adjournment, and received but scant attention in the Senate on the final Saturday morning. The vote in its favor in the latter body was 35 to 7 .

Large amounts of gold were immediately coined, and by I840 began that excess of exports over imports of silver which has been interrupted only three times since then. $\dagger$

After 1843 the amount of gold coined exceeded that of silver. The discovery of gold in 1848 somewhat reduced its

* Sumner, "Andrew Jackson," p. 333.

+ 1843, 1846-47, I86!. 
value in the years following, and thus greatly. increased the divergence between the mint rate and the market rate of the metals. In I850 it became difficult to keep fractional silver in circulation. The small coins even were worth more as silver than as change, and their worth increased in $185 \mathrm{I}$ and 1852. Silver was thus gradually demonetized under the action of the law of 1834 . The monetary standard of the United States since 1837 has been 23.22 grains of gold.

\section{FRACTIONAL SILVER COINS.}

The second change of importance which was made in our coinage system was the reduction made in the weight of the fractional silver coins under the Act of February 21, 1853 . By the law of 1792 they had contained proportional parts of a dollar-412 $1 / 2$ grains gross weight, after 1837 . By the statute of 1853 they were reduced in weight to parts of 384 grains to the dollar and coined only on Government account. The provision for free coinage of the silver dollar was not changed, but after the act went into effect no deposits of silver bullion were received for the purpose of coinage into fractional coins, except from the treasurer of the mint. The coins were to be sold in exchange for gold in amounts of $\$ 100$ worth or more, face value, and the amount of quarterdollars, dimes and half-dimes to be manufactured was left to the discretion of the Secretary of the Treasury, the treasurer of the mint being authorized to purchase the necessary amount of bullion. The smaller silver coins, parts of a dollar, were thus made subsidiary and put on the same basis as the minor or token coins, the profit on their coinage being from time to time turned to the account of the Treasurer of the United States. By this act they were made legal tender only in payment of debts for sums not exceeding $\$ 5.00$. This amount was increased to $\$ 10.00$ by the Act of June 9, I 879 .

This Act of 1853 was the logical outcome of the increase in the production of gold after 1848 and the consequent fall 
in its value as compared to silver. Soon after the discovery of new mines of gold the silver coins rose to a premium of five per cent and quite rapidly disappeared from circulation. The coinage at the mint fell from $\$ 2,55^{8,580.00}$ in 1846 to only $\$ 774,397.00$ in $185^{1}$. Small change became very scarce. The demand for it is clearly shown in the mintage of the depreciated three cent piece which was only $3 / 4$ fine.* The demand is also shown to have been urgent by a consideration of the amount of the smaller silver coins sold after I 853 -an average of over $\$ 5,000,000$ worth annually for the five years $1853-58$.

Gold and silver coins were now again unequal in value. Unless the variation was to be of temporary duration- an hypothesis which did not appear reasonable at the time; unless the equilibrium was soon to be restored by natural or industrial causes and conditions, it was a matter of necessity that some alteration be made. The every day convenience of trade and industry demanded it. The alternatives were an increase of four or five per cent in the weight of gold in the gold coins, or a corresponding decrease of the silver in the silver coins. To the former remedy Mr. Skelton offered the objection $\dagger$ that increase in the weight of the gold currency of the country would compel a man possessing a quantity of gold coin to receive less than a dollar for that piece of money stamped with one dollar upon its face. To prevent this injustice the government might redeem the old coins at their face value in the new ones to be issued, at an expense of $\$ 15,000,000$ or $\$ 20,000,000$. The one alternative government could not afford; the other was virtual robbery of the individual by Act of Congress. "We should meet that difficulty when we return home to our constituencies," remarked Mr. Skelton. Mr. Dunham added: "It is using the power of the government for the benefit of

\footnotetext{
* It amounted to wearly $\$ 1,1 \infty, 000, \infty$ in the years 185 I to 1853 , while only $\$ 200$,000 worth was issued between 1853 , when the coin was reduced (or rather raised) to the standard of nine-tenths fine and 1873 , when its coinage was discontinued.

$\dagger$ Congressionai Globe, Vol. XXVI p. 492.
} 
capital at the expense of labor-of the rich at the expense of the poor." *

It is not to be wondered at that the average Congressman should choose rather to reduce the fractional silver than to raise the value of the gold coin, although it was clearly recognized that the disparity in the coins existed because of a fall in the value of gold and that so-called theoretical justice demanded an increase in the weight of the gold coin as a means at once of equalizing the coins and maintaining the standard.

That the act could or would depreciate the standard of value, or that it did so, is not apparent. True, fractional silver coins are debased coins. They are token coins, and the government makes a profit at present prices of about forty $t$ cents on every dollar's worth sold. But they are worth their face value by reason of the fact of the limitation of the supply. There is a government monopoly. The only way to obtain two half-dollars is to pay their nominal value to the government in legal tender. Thus, the standard of value cannot be affected. People are not deprived of their rights, laborers are not robbed of their hire, by being paid in the debased silver coins.

It was a condition and not a theory which presented itself in $185^{\circ}$. It was a practical difficulty under which the country was laboring. The small paper tickets of an earlier generation were again coming into use. The object of the law was simply to supply small silver change-a much more convenient form of currency. As stated in a petition from the New Jersey Legislature, "It could not in the slightest degree disturb the monetary affairs of the nation, or infringe existing rights in contracts." It might with some propriety be urged, as was stated by Mr. Jones, of Tennessee, that "making gold the standard was something like making standards of tobacco, rice, cotton, or any other of the staple productions of the country." Gold at the time

* Appendrx, Congressional Globe, Vol. XXVII., p. IgI.

† Estimating silver at 85 cents per ounce. 
seemed almost as unstable a measure as silver became in the years following 1873 . But depreciation does not necessarily follow debasement, and in the instance in question was certain not to follow. Debasement of the fractional silver coins had no more effect than the debasement of the copper coins on the fluctuation of the money unit. They were not allowed to decline in value.

Despite the evident public need for a simple and convenient retail currency, but little interest was taken in the bill. It was first introduced by the Finance Committee in the Senate, March 8, r852. On the twenty-ninth Mr. Hunter asked the Senate to take it up, remarking: "I believe there is no objection to it. We can pass it this evening." There appeared to be no objection, and it was ordered engrossed for the third reading, and passed without discussion on the day following. For some reason it did not appear in the House until May 3. It was then referred to the Committee of Ways and Means, but was not brought up for discussion until February I, 1853. On that day it was introduced with a speech by Mr. Dunham, explaining its provisions and the reasons for some four or five proposed amendments. It was discussed on the two following days, but only during the morning hour, and was not again brought up until February 15, when the amendments were voted down by large majorities, and the bill passed as it came from the Senate- "Ayes, 94 ; noes, not counted."

The opposition to the bill in the House came almost entirely from those who insisted that, in spite of the limitation as to the amount to be coined, the bill depreciated the standard and provided for the issuance of a new kind of coin which would complicate rather than simplify the monetary system. The reverse proved to be the case. The coin introduced increased the uniformity in our coinage system and met the wants of the trading community.

There seems to have been no opposition on the part of bimetallists. 
The discussion of the bill does not indicate the existence of any firm conviction of the desirability or the feasibility of securing concurrent circulation by making the mint ratio the same as the market ratio. The usual charges were made that the government was "tinkering" with the currency and that the act was mere legislative quackery, and inaction was declared to be the best remedy for the existing trouble. But no serious effort was made to obtain bimetallism. For a number of years gold had been unmistakably the standard and the supporters of the measure distinctly avowed their intention to let it remain so ; to cause legal recognition of the fact, and in part to adapt silver to this standard by reducing the weight of the coins most needed in retail trade so that they would be below par as merchandise. Nothing is said in the act about the dollarthe coin which practically had never been coined; but in his speech introducing the bill in the House, Mr. Dunham expressed the desire of the committee to have the standard currency consist of gold only, and stated that the effect of the bill would be to make the proposed silver coins entirely subordinate by reason of the degree of their debasement; that they would be used rather as token than as standard currency, "applicable and convenient, not for large but for small transactions."

It is indicative alike of the small amount of interest manifested in the subject and of the carelessness of legislators that the first section of the bill stated that it was to go into effect in June, 1852. It was the expectation of the Senate Committee that it would be passed the first session, but it was delayed until near the end of the second session and passed in the House as it came from the Senate ; this provision of the first section, therefore, required the impossible, and it was necessary to rectify the blunder by a clause in the Deficiency Bill. The Act went into effect April I, 1853 .

In the light of the current discussion of the currency 
question it is interesting to note that the protective argument was used in $\mathrm{r} 853$ in behalf of a single gold standard and a gold currency just as it is now urged in favor of the free coinage of the silver dollar. Gold is the production of our own country: silver is not. Let us, therefore, it was urged, use our own productions and in so far increase their value. It is another instance of attempt to make private interest appear public blessing, if not to substitute private for public benefits.

After I848 the amount of gold coined each year at the mints of the United States increased as follows, in millions of dollars: 1849,9 ; 1850,32 ; $1851,62.6$; $1852,56.8$. No one could suppose that such a quantity of coin would be at once introduced into the circulation of the country. Putting the metal through the mint was simply an easy way of getting it manufactured into a marketable form. Provision was consequently made in this Act for the manufacture of bars or ingots, either of pure or standard metal, at a charge, not above cost, to be fixed by the Secretary of the Treasury. By this provision it becomes possible, in part at least, to separate the metal designed for use in the arts from that which is to go into circulation as coin and to place the expense for manufacture of the latter only on the government and thus on the general public.

REORGANIZATION OF THE MINT.

The act of February 12, r873, was at once a codification and a revision of the laws relating to the coinage system of the United States and to the business of minting. It is entitled: "An Act revising and amending the Laws relative to the Mints, Assay-offices, and Coinage of the United States." By it our coinage system was somewhat extended and the work of making coins more carefully systematized. The many provisions of the sixty and more different laws regarding the mint and its branches, the assay offices, and the coinage of the United States, which had been enacted in 
the eighty years preceding and were still in force, were incorporated into a single statute. Inconsistencies were removed; discrepancies rectified; and the whole body of enactments simplified as far as possible. It was spoken of in debate* as " a code for the government of the whole subject, carefully drawn, after months of thorough preparation, as the result of the best judgment of the department and the country."

The Bureau of the Mint was established in the treasury department, for purposes of supervision over the various branches of the service, and for the collection of statistics. Further changes in the law were adopted, but they relate chiefly to the business methods employed, or to be employed, in the mints and the assay offices. The law principally concerns administration, specifying the manner in which government officers shall perform their duties. It had been drafted by the Deputy Comptroller of the Currency, Mr. John Jay Knox, and was designed to facilitate public business and to promote the efficiency of the government service.

Three changes were made in the kinds of coin to be issued. One copper coin, the two-cent piece, was omitted from the list of coins the Director of the Mint was authorized to have coined. The coinage of three silver coins, the half-dime, the three-cent piece and the dollar, was also discontinued. The manufacture of a trade dollar was authorized. But no change whatever was made in regard to the gold coins to be manufactured.

Purely practical reasons were given for each of these changes in the list of coins. The two-cent piece had not found a ready market. The public did not care for it, though it might make use of a two-and-a-half-cent piece. The half-dime and three-cent piece in silver were inconvenient coins, like the gold dollar, which has since been discontinued. $\dagger$

\footnotetext{
* By Mr. Casserly, in the Senate, January 9. 1871. Congressional Globe, 3d Sess., Forty-first Cong. p. 372.

t Act of September 26,1890 . See Statement $A$ in the Appendix.
} 
The silver dollar for some years had been worth about $\$ 1.03$ in gold; since the passage of the Gold Coin Bill of 1834 the fine silver in a silver dollar ( $371 / 4$ grains) had been worth somewhat more than 23.22 grains of fine gold, and as a consequence the silver dollar had not circulated in the country. It was used chiefly " as a convenient portion of silver in the laboratory of the metallurgist, or was hoarded as an object of curiosity." $*$ The average amount annually issued from 1839 to 1869 was only a little over 100,000, and of the total $8,031,238$ issued between 1792 and 1873 , nearly one-half were made in the years following 1865 , and were manufactured almost exclusively for export. In 1804, when it became apparent that these coins were not used to form part of the currency of the country, but were exported to the West Indies, the administration saw fit, without the sanction of the law, to discontinue their issue. In 1873 the officers of the government recommended simply that authority to manufacture be withdrawn, and it was so enacted.

Quite other reasons have since been assigned by some, both for the recommendation and for its acceptance by Congress. The anticipated decline in the value of silver, it has been claimed, led to the demonetization of silver in 1873 . Some feared and many fully expected a change in the relation of the two metals, and hence secured a revision of the law in order to insure themselves against loss or to prepare the way for reaping immense harvests through the fluctuation in prices and the fall in values. On the other hand, it is maintained that the great decline in the value of silver was as little foreseen, and could have been as little foreseen, in 1873, as was the earlier decline in the value of gold. Certainly, accusation of the legislators of either period is, to say the least, uncalled for.

The debates of 1873 , as of 1853 , have record of no bimetallic controversy. In each instance, more particularly

* Report of the Comptroller of the Currency, 1876, p. 168. 
the latter, its occasion had been lacking. Between 1862 and 1876 we had a paper currency. Both gold and silver coins of every kind and description, and in a measure even copper coins, were driven from circulation by the notes of the treasury, of the national banks, and of individuals. They had ceased to be part of the circulating medium of the country. They would be returned only upon the withdrawal of the depreciated paper. It was even questioned in debate why the government should consider the relative merits of two kinds of coin neither of which the country possessed. As between the two, there was apparently no thought of so changing the mint rate as to insure their joint circulation, except on the part of those who opposed any debased currency whatsoever-even the fractional. No one proposed to attempt the re-establishment of bimetallism. For that purpose, the depreciation of the silver dollar three per cent or more would have been necessary, and some plan for forcing the depreciated paper to par and maintaining it in a state of convertibility must have been adopted.

How far coming events cast their shadows before is ever a difficult matter to determine, but that the changes of the years from $187 \mathrm{r}$ to 1876 could have been anticipated by $\mathrm{Mr}$. Knox in preparing his report in 1869 hardly seems probable. It is certain that the average Congressman in 1873 would not have found it possible to make the most vague approximation to the rate which was necessary to secure bimetallism throughout the decade that followed. That the victor in the Franco-Prussian war would be able to compel the payment of a gigantic war indemnity of $\$ 1,000,000,000$, and would make use of the opportunity to change the currency of Germany from silver to gold, as a means of aiding industrial development; that between $187 \mathrm{I}$ and 1874 nearly every country in Europe would close its mint to the coinage of silver and keep it closed; and that the demand for silver in the countries of the East, India and China, would greatly decline; that the production of silver would double, treble 
and quadruple even between 1868 and 1878 ; that an almost unprecedented industrial depression would follow the panic of 1873 ; that these, or any such fortuitous concatenation of events could have been foreseen, and the fall in the value of silver, as measured in gold, been predicted with any accuracy, is highly improbable. In any case the very best policy, the one which most completely protected the interests of the whole community was, perhaps, the one adopted in the Act of I 873 .

The fall in silver, coming as it did so shortly after the failure of the Greenback party in 1874 , gave rise to bitter feelings against those who secured the enactment of the Mint Law of 1873 . Extremists even went so far as to say that silver had been demonetized by clandestine legislation. Nor has this belief disappeared with the progress of time; it is still current, though quite unwarranted, as shown by the history of the bill in its passage from drafting to final enactment. It was practically before Congress and before the country for about four years. In his report in 1869 the Director of the Mint urged the restoration of a silver currency "for change," in lieu of the postal and small-note currency, as the first step toward and " an important adjuvant to a general resumption of specie payments." A year later he stated that a number of our leading commercial newspapers had emphatically endorsed the plan and he expressed the belief (1870) that the product of silver in Nevada and Colorado would be sufficient to meet the demand. His proposition was for a very much more debased kind of coin than those formerly in use, and in defence of the system he quoted the following significant language: "This is not a scheme for debasing the standard of value. Its only object is to restore silver on such a basis, under legal sanctions, as will enable it to keep its subsidiary place, whether the chief currency be paper, as it now is, or gold, as we hope it will soon be." **

* Finance Report, 1870, p. 422. 
The draft of a bill in which the plan was systematically worked out had been sent, during the year 1869 , to prominent financiers and the important government officials, for suggestion and comment. In its perfected form it was introduced into the Senate by Mr. Sherman, April 28, I870, and referred to the Finance Committee. The letter from the Secretary of the Treasury and the report by Mr. Knox explaining the provisions of the bill were printed with the bill.

After a careful investigation the bill was reported in December following. It was discussed during the morning hours of January 9 and January Io, $187 \mathrm{I}$, and passed on the second day by a vote of 36 to 14,22 being absent. Just a year later, January 9 and 1o, 1872 , the bill was discussed in the House,* and recommitted. On February 9 it was again introduced. Mr. Hooper, of Massachusetts, who then had the bill in charge, explained in his speech opening the discussion that Section 16 provided for a dollar coin of 384 grains of silver $\frac{9}{10}$ fine, " making it a subsidiary coin in harmony with the silver coins of less denomination, to secure its concurrent circulation with them." $\dagger$ He was followed by Mr. Stoughton, of Michigan, who continued the explanation of the bill. In the course of his speech he made the following perfectly plain statement: $\$$ "The office of the silver or 'subsidiary' coins is to supply the public want for small change. They are made the tokens of value, not the value itself, and are designed only for exchange and circulation at home, up to but never in excess of the requirements of trade."

It would thus appear that the Committee of Coinage, Weights and Measures was not endeavoring to conceal its intentions. They proposed to carry out the recommendation of the Director of the Mint and provide for the restoration of silver to its place as a subsidiary coin in our currency,

* Mr. Kelly had introduced the bill (H. R. No. 5) in the new Congress

† Congressional Globe. Second Session Forty-second Congress, p. 2306.

$\ddagger$ Congressional Globe, Second Session Forty-second Congress, p. 2309 . 
making this the first step toward a resumption of specie payments and a complete restoration of the currency of antebellum days. The final vote in the House was taken under a suspension of the rules, when a substitute bill was passed May 27, 1872, by a vote of $\mathrm{r}$ ro to $\mathrm{I}_{3}$.

Nearly another year elapsed before the bill was passed in the Senate, on January 17,1873 . It had received twenty amendments on its journey through the latter body. The House did not concur. The Senate insisted. Conference became necessary to pass the bill. The report of the Conference Committee was agreed to, the House receding from its opposition to the amendments of the Senate numbered I, 2, 3, 5, 7, IO, II, I3, I4, I5, I6, I7, I8 and 20, and the wording of the other amendments being so changed as to be acceptable to both Houses. The exact character of the bill was thus finally determined in conference committee, but its main features, so far as a change of the coinage is concerned, had been under contemplation for nearly four years. If the charge of clandestine legislation is preferred against the legislators of 1873 it must be urged with equal force at the bar of public opinion against many another Congress whose most important acts have been shaped by a Conference Committee chosen to remove the points of disagreement between Senate and House.

As late as the beginning of the year 1872 it appears to have been a matter of doubt whether the silver coins were sufficiently debased under the Act of 1853 , to keep them in circulation. On January $8 \mathrm{Mr}$. Kelly introduced a resolution " which was read, considered, and adopted by the House," instructing the Committee on Coinage, Weights and Measures " to inquire and report whether the intrinsic value of the silver coinage is not above that of other nations and greater than is necessary in coins designed for subsidiary purposes only, and to be retained permanently in the country."

The difference in European systems of coinage was five per cent, whereas in ours the smaller silver coins were then 
worth only about four per cent less than the standard gold coins. To-day they are worth about forty per cent less, and the inducement to counterfeit has become correspondingly great.

Moreover, the recommendations of the mint authorities and the action of Congress were quite in harmony with another attempt which was making at this time-that in favor of an international coinage system.

On February 8, r87o, Mr. Sherman introduced the following resolution in the Senate:

" Resolved, That the President be requested, if not incompatible with the public interests, to invite a correspondence with Great Britain and other foreign Powers, with a view to promote the adoption by the Legislatures of the several Powers of a common unit and standard of an international gold coinage, and that such correspondence be submitted to Congress for its information and action."

The Forty-first Congress was at least consistent. It did not attempt, as did a later one, to secure an international agreement for a common unit and by its own act put another barrier in the way. It rather undertook to bring the currency system of the United States into accord with that of the most completely developed of her sisters in the family of nations.

Finally, as if to remove the last shadow of doubt as to the definite intentions of the administration, we have the recommendation of the Secretary of the Treasury in his report for 1872, issued when the bill was in its last days. Silver had already begun to depreciate. Its use as currency had been discontinued by Germany and some other countries. The amount mined was at the same time increasing. Believing that the depreciation of silver was likely to continue, the Secretary urged such alterations in the Mint Bill as would "prohibit the coinage of silver for circulation in this country." He held that no attempt should be made to introduce the use of silver as currency, but " that the coinage should be limited to commercial purposes, 
and designed exclusively for commercial uses with other nations."

It was in carrying out the policy, recommended by the Secretary of the Treasury, that authority was given to manufacture the "Trade-dollar." In attempting to determine the motives which led to the discontinuance of the silver dollar due consideration must be given to this fact, that the same act grants the right to have the more valuable trade-dollar manufactured at the mint. The history of the trade-dollar also offers an exceedingly interesting lesson in the operation of currency laws.*

Section 21 of the Act of 1873 provided that any owner of silver bullion might " deposit the same at any mint to be formed into bars, or into dollars of the weight of four hundred and twenty grains Troy, designated in this act as trade dollars, and no deposit of silver for other coinage shall be received, . . . the charges for converting standard silver into trade dollars shall equal but not exceed . . . the actual average cost to each mint and assay office of the material, labor, wastage and use of machinery employed," these to be determined by the Secretary of the Treasury. Under this provision the amounts issued in millions of dollars were: in $1873,1.2$; in $1874,4.9$; in $1875,6.3$; in 1876 , 6.2 ; in $1877,13.1$. The coinage was partially suspended in October, 187,7 , and finally discontinued by the act of February 22, 1878 .

The legal tender quality of the trade-dollar, limited to amounts not exceeding five dollars in any one payment, was entirely removed by the act of July 26,1876 ; yet as many of these coins were made after this date as before, and they remained in circulation for a number of years after their coinage had been entirely disallowed. That is to say, the American people persisted for several years in having manufactured and in using a coin to which Congress gave no sanction

* A detailed accout of the life of this coin is given in the report of the Director of the Mint for 1887, pp. 96-100. 
other than the guarantee of an honest and efficient mint. From 1873 to 1875 these coins cost somewhat more than a dollar each in the United States, and hence no one could afford to use them as money, either in paying debts or buying goods. It was only by exporting them to China and the East that the expenses of their coinage could be met. In 1876 and 1877 , however, they cost less than a dollar apiece to manufacture, $*$ and as the public generally continued to receive them at their face value, holders of bullion found it profitable to send it to the mint for coinage, as prescribed by the Act of 1873 , into a 420-grain trade-dollar.

Of the total amount coined, $\dagger$ one-fifth $(7,689,036)$ was redeemed at face value, in exchange for standard silver dollars or subsidiary silver coins, under the act of March 3, 1887. Nearly all the remainder have been permanently exported. So far as our currency is concerned, therefore, the trade-dollar has become a thing of the past.

The Act of 1873 thus appears to have been an attempt to remonetize rather than to demonetize silver. By the Act of 1834 silver, as compared with gold, had been undervalued in our coinage. From about 1840 down to 1875 the $371 \frac{1}{4}$ grains of fine silver in a dollar had been worth more than the 23.22 grains of fine gold in a dollar-from one to ten cents more. During all this time Congress had failed to rectify the mistake, if mistake it was, that had been made in 1834 , and as a consequence the American people had used a gold currency. Silver had not been monetized; indeed, it was demonetized by the public during this period. The only monetization took place under the Act of 1853 , debasing the fractional silver currency and limiting the right of manufacture by abolishing "free coinage" and creating the government monopoly.

The Act of 1873 was supplementary to the Act of 1853 and conceived with the same intent. The circulation of

* See Diagram.

$+35,965,924$. 
postal currency had driven silver coins out of circulation during the Civil War and the years subsequent thereto. The proposition was made in 1869 to restore silver to its position as a subsidiary coin, the supply from Nevada and Colorado, it was believed, making this feasible. Any excess in the silver product for export was to be in the form of a "trade-dollar." An American silver coin had never been the chief component of American currency, and there was at that time no apparent reason for attempting to introduce it. For a generation silver had been used as the metal of our subsidiary coins. It remained, then, to bring the dollar into harmony with the fractional coins or to retire it from the circulation. The latter alternative was chosen, although the former had been recommended. Provision was made at the same time for the manufacture of coins of a convenient form, with quality and quantity of metal marked upon each, which could be used in trade with countries having a silver currency.

The important effect of this law, and of the provision of the revised statutes (1874) which deprived the silver dollar of legal tender quality, was that they prevented a use of silver which, under laws previously in force, would inevitably have followed the fall in the value of silver (I876) and the failure of the Greenback movement. Whether or not this was a desirable result is a much disputed question. The belief that it was not has led to the persistent effort of the last fifteen years to extend the use of silver. It is with the passage of the Act of January $\mathrm{I}_{4}, 1875$, providing for the resumption of specie-that is, gold-payments on the outstanding obligations of the government, that the real bimetallic controversy in this country begins. It has been carried on alike by those personally interested, as they believe, in maintaining the stability of our measure of value and standard of payments and by those who are anxious for the general welfare and believe that industrial growth and prosperity, as well as political justice, demand a composite unit of value. 
Thus far this movement for bimetallism has resulted in three apparently quite fruitless attempts to secure international agreement regarding the coinage of gold and silver, * and in the two acts requiring the United States Government to purchase silver as the basis of a paper currency.

By the Act of February 28, I878, the coinage of the standard silver dollar was authorized and its legal tender quality restored. But the coinage was fixed within definite limits and to be made on government account only. The Secretary of the Treasury was instructed to purchase not less than two nor more than four million dollars' worth of silver per month and have it coined into standard dollars. He was also authorized to issue certificates for the deposit of these coins, which should be receivable for customs, taxes and all public dues, and when so received might be reissued. Nearly 400,000,oo were coined under this act, of which about $60,000, \infty 00$ remain in circulation; the remainder are covered by certificates, or are lying idle in the vaults of the government.

The Act of July I4, I89o, known as the Sherman Act, directs the Secretary of the Treasury to purchase four and one-half million $(4,500,000)$ ounces of silver per month, or such part thereof as may be offered for sale at prices below \$I.29 per ounce, and to issue Treasury Notes in payment. These notes are a legal tender at their face value " in payment of all debts, public and private, except when otherwise expressly stipulated in the contract." They are redeemable in either gold or silver coin at the option of the secretary. The government is thus made a regular purchaser of silver, which it uses as the basis of a paper currency that increases from $\$ 40,000,000$ to $\$ 60,000,000$ a year, according as the price of silver rises or falls. Thus far the administration, Democratic as well as Republican, has been able to redeem the Treasury Notes in gold.

School of Social Economics.

ARTHUR B. WOODFORD.

* Held at Paris in 1878 and $188 \mathrm{r}$, and at Brussels in 1892 . 


\section{STATEMENT A.}

Showing the various coins issued from the mints of the United States, the date at which they were authorized and discontinued, and the legal tender quality of each.

GoLD (6, 2 discontinued).

$$
\text { Authorized. Discontinued. Legal Tender. }
$$

Double-eagle, . . Mch. 3,1849, . . . . . For any amount.

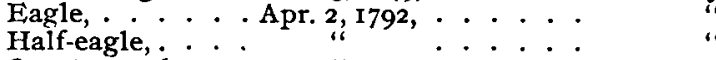

Quarter-eagle, . .

Dollar, . . . Mch. 3, 1849, Sept. 26, 1890,

Three-dollar piece, Feb. 21,1853 ,

"،

Silver $(8,4$ discontinued).

Dollar, . . . Apr. 2, I792, . . . (Except I874-I878).

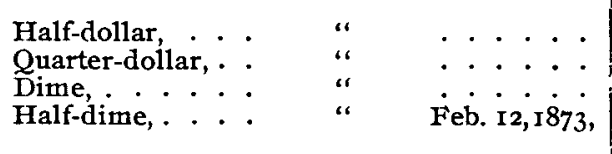

Three-cent piece, Mch. 3, I85I, For any amount until Feb. 2r, 1853; then not exceeding $\$ 5.00$ until June 9, 1879 ; not exceeding $\$ 10.00$ in any one payment since then.

Twenty-cent piece, Mch. 3, I875, May 2, I878, $\{$ For any amount not Trade-dollar, . . Feb. I2, I873, Feb.22, I878, \{ Not exceeding \$5.00.

CoPPer (2, discontinued).

Cent, . . . A Apr. 2, 1792, Feb. 21, 1857,

BRONZE (2, I discontinued).

Two-cent piece, . Apr.22, 1864, Feb. 12, 1873, \{20c. until Mch. 3, '65. Cent, ..... $\quad \ldots .\left\{\begin{array}{l}\text { Ioc. till Mch. } 3, \text { I865. } \\ \text { 4c. till Feb. r2, I873. } \\ \text { 25c. thereafter. }\end{array}\right.$

Nicked ( 3,2 discontinued).

Cent, . . . . Feb.2 I, 1857, Apr.22, I864,

Three-cent piece, . Mch. 3, I865,Sept.26, I89o, $\left\{\begin{array}{l}60 c . \text { till Feb. I2, '73. } \\ 25 \text { c. thereafter. }\end{array}\right.$

Five-cent piece, . May 16,1866, .... $\left\{\begin{array}{l}\$ 1.00 \text { till Feb. 12, '73. } \\ 25 \text { c. thereafter. }\end{array}\right.$ 


\section{STATEMENT B.}

Showing the weight and fineness of the gold and silver coins under the various statutes, the number of grains to the dollar being given in each case.

Gold coins, April 2, I792.
Gross
weight. Standard. metal.

Gold coins, . . . . 27

Silver coins, ... $4^{16}$ $\frac{11}{1} \frac{1}{2} \quad 24 \frac{3}{4}$

Ratio of pure metal,

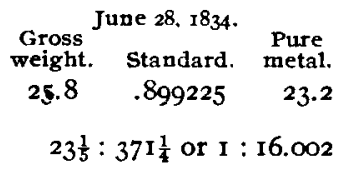

Silver coins, January 18,1837 Gross Pure weight. Standard. metal. .............. 412 $\begin{array}{lrr}25.8 & 9 & 23.22 \\ 412 \frac{1}{2} & \frac{10}{10} & 371 \frac{1}{4} \\ & & \text { I }: \text { r } 5.998\end{array}$

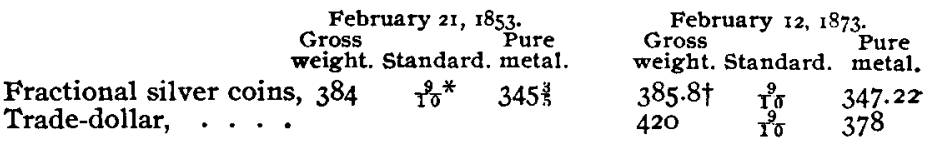

\section{STATEMENT C.}

Showing the coinage of gold and silver at the mints of the United States by periods, together with the total production from the mines of the country since 1792 .

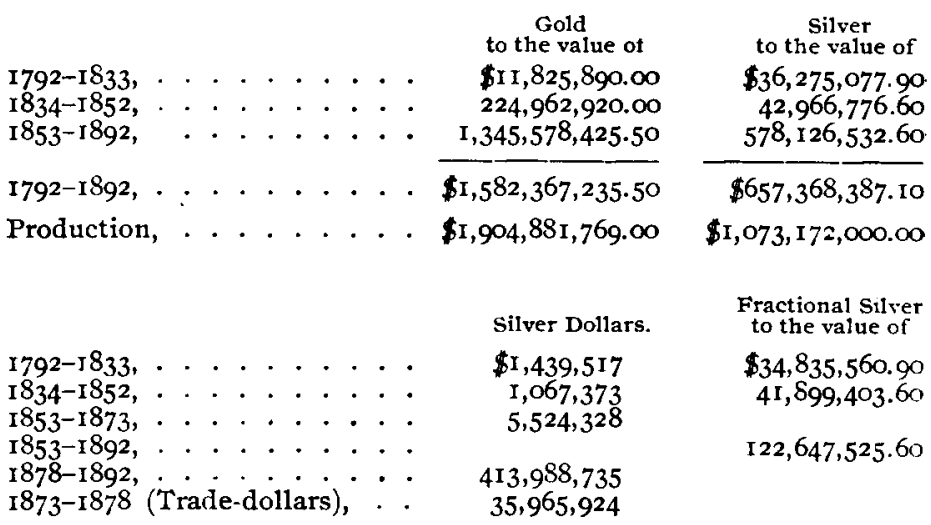

* Except the three-cent piece (March 3,1851 ), which was $3 / 4$ fine; weight changed to standard March 31853 .

$\dagger$ Equals 25 grams 


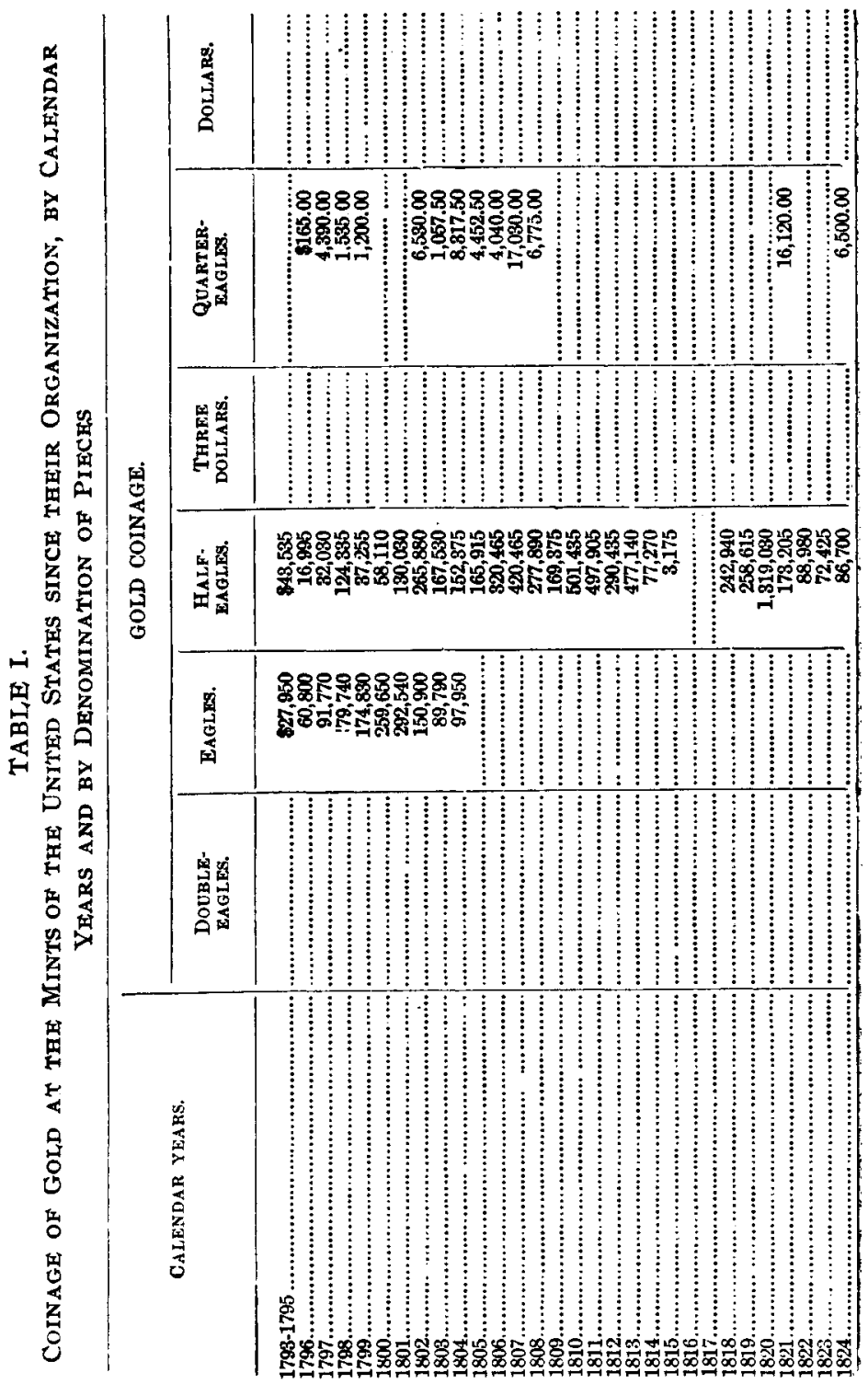




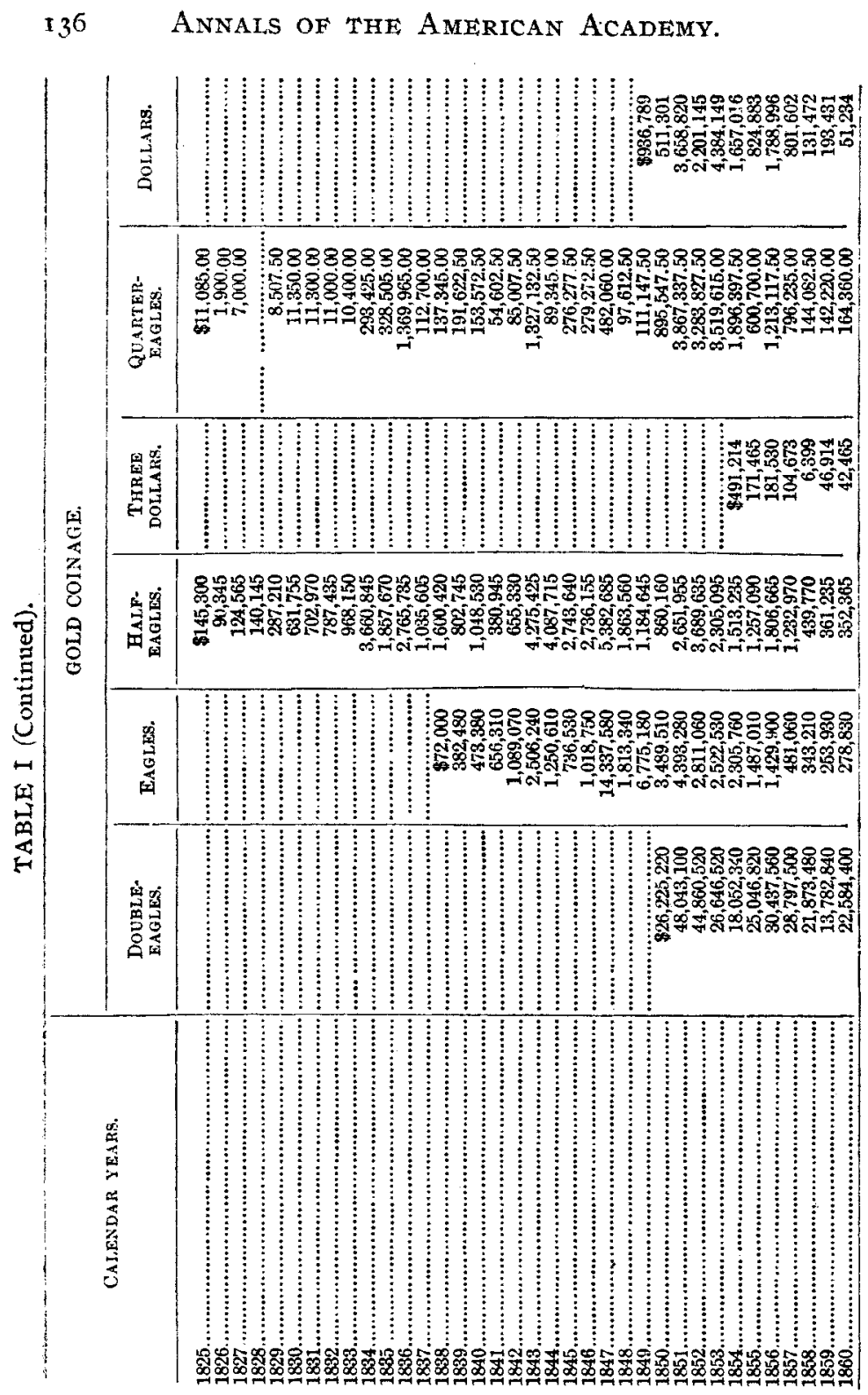


USE OF SILVER IN THE UNITED STATES.

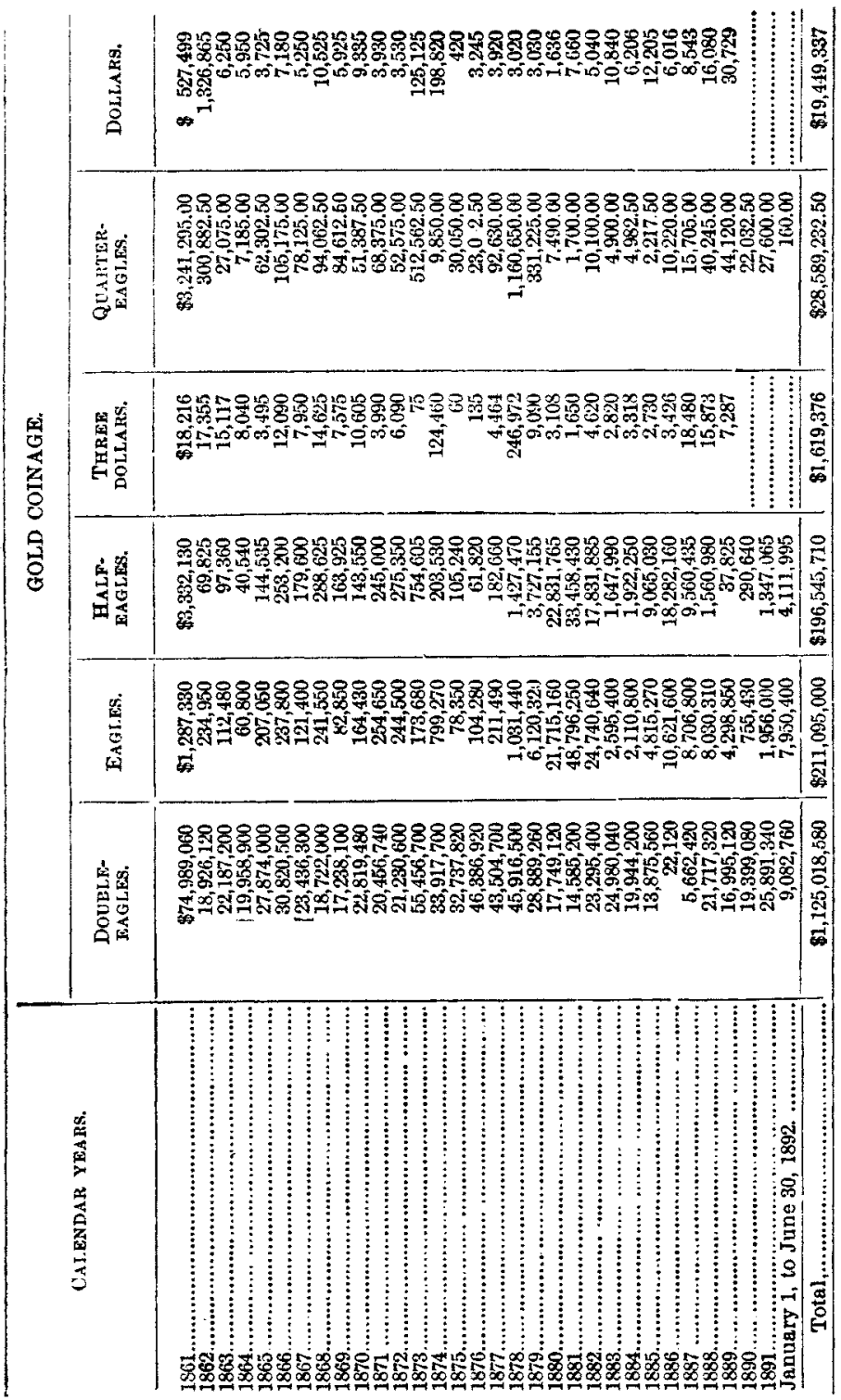




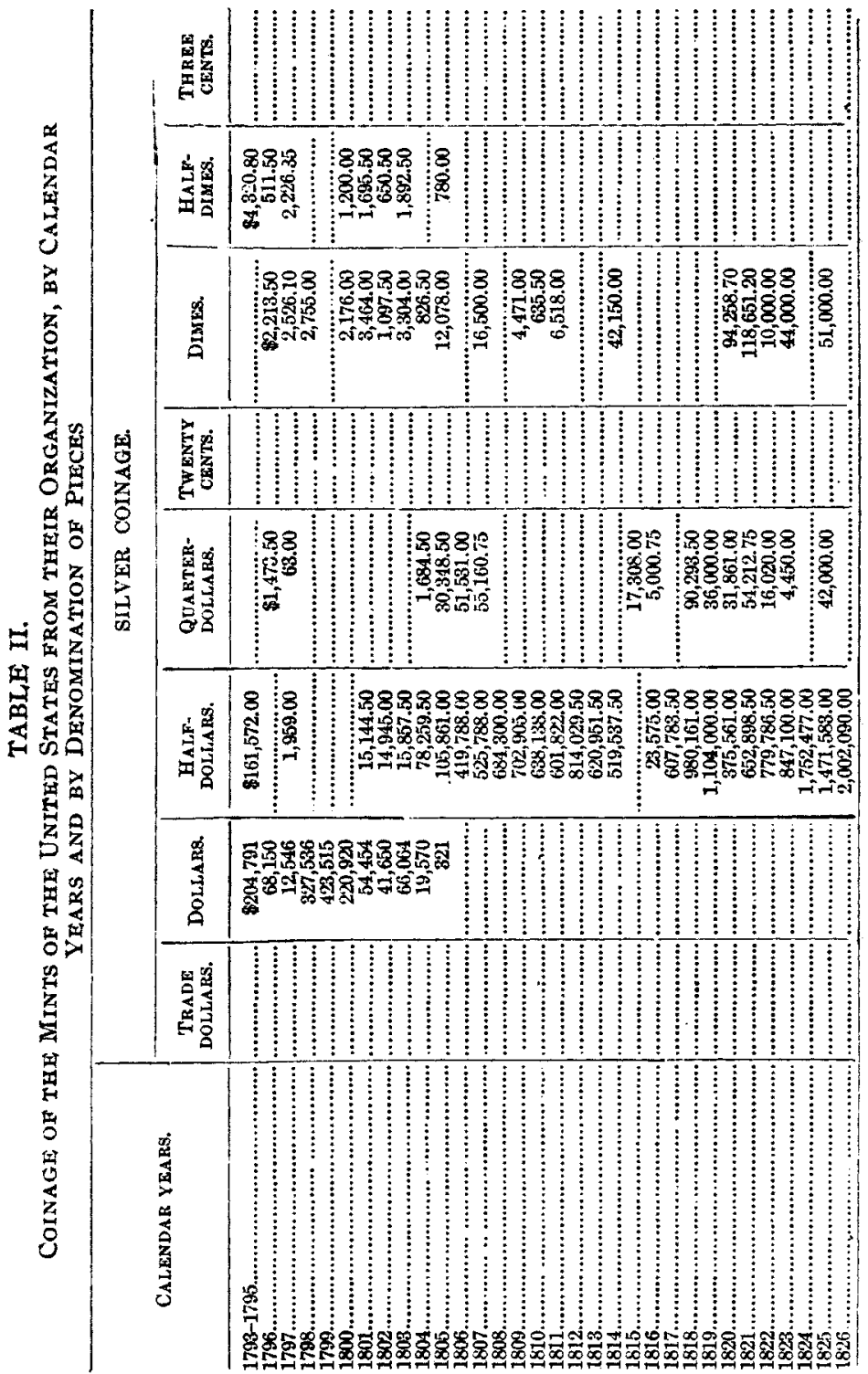


UsE OF Silver IN THE UNITED States.

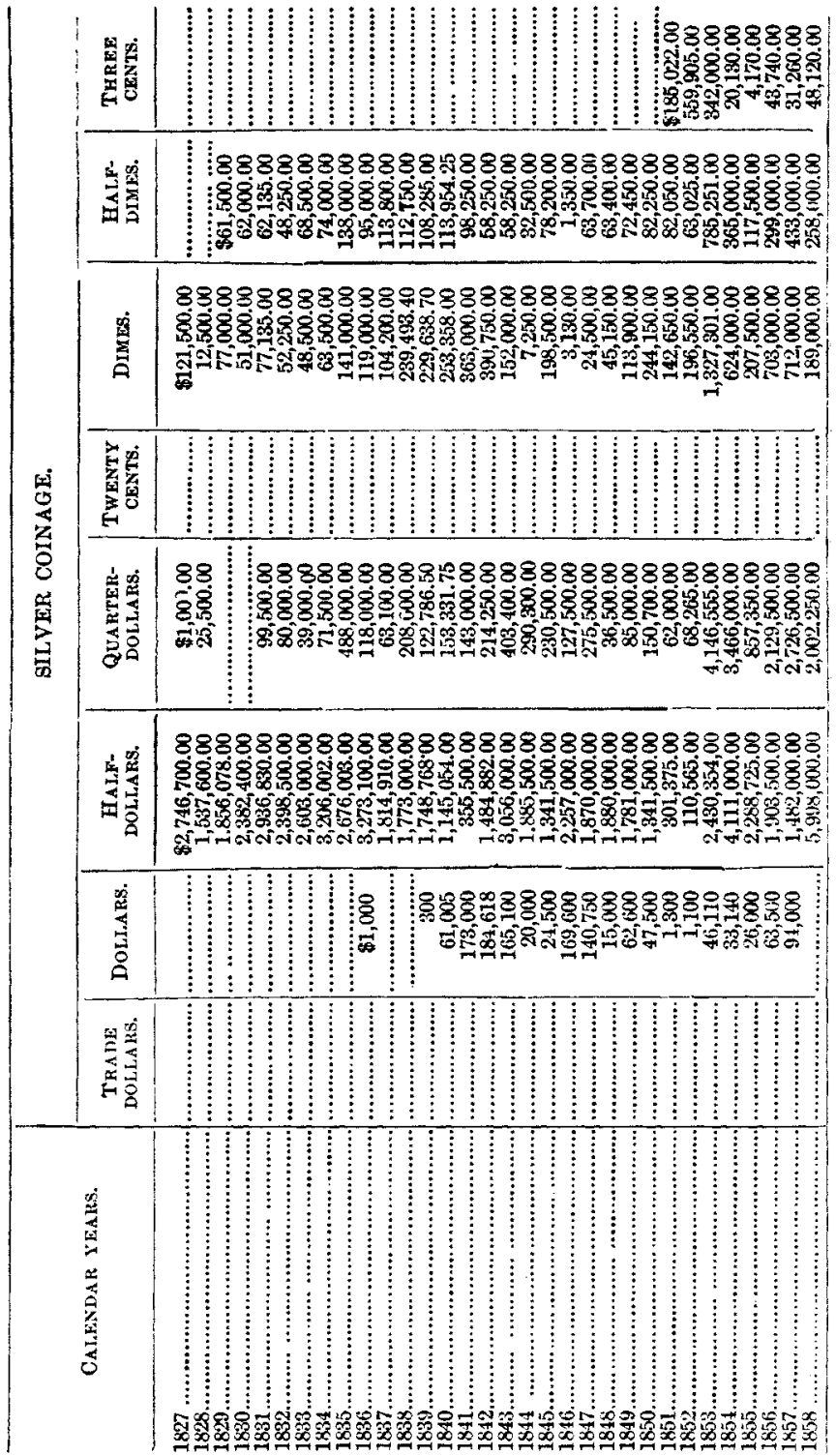


I40 Annais of the American Academy.

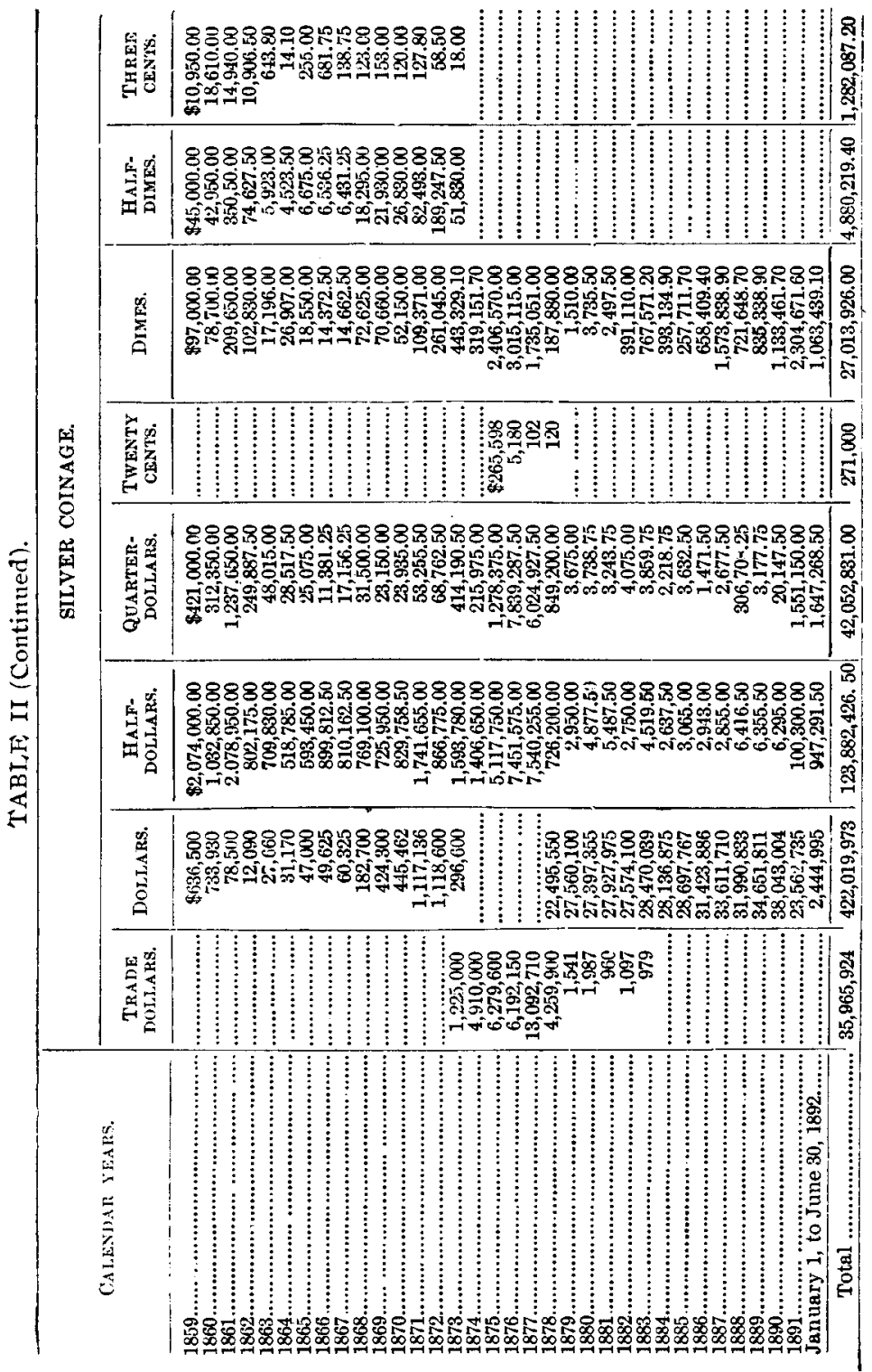


Diagrax I.-Gold and Silver Coinage of the Mints of the United States (1834-1892).

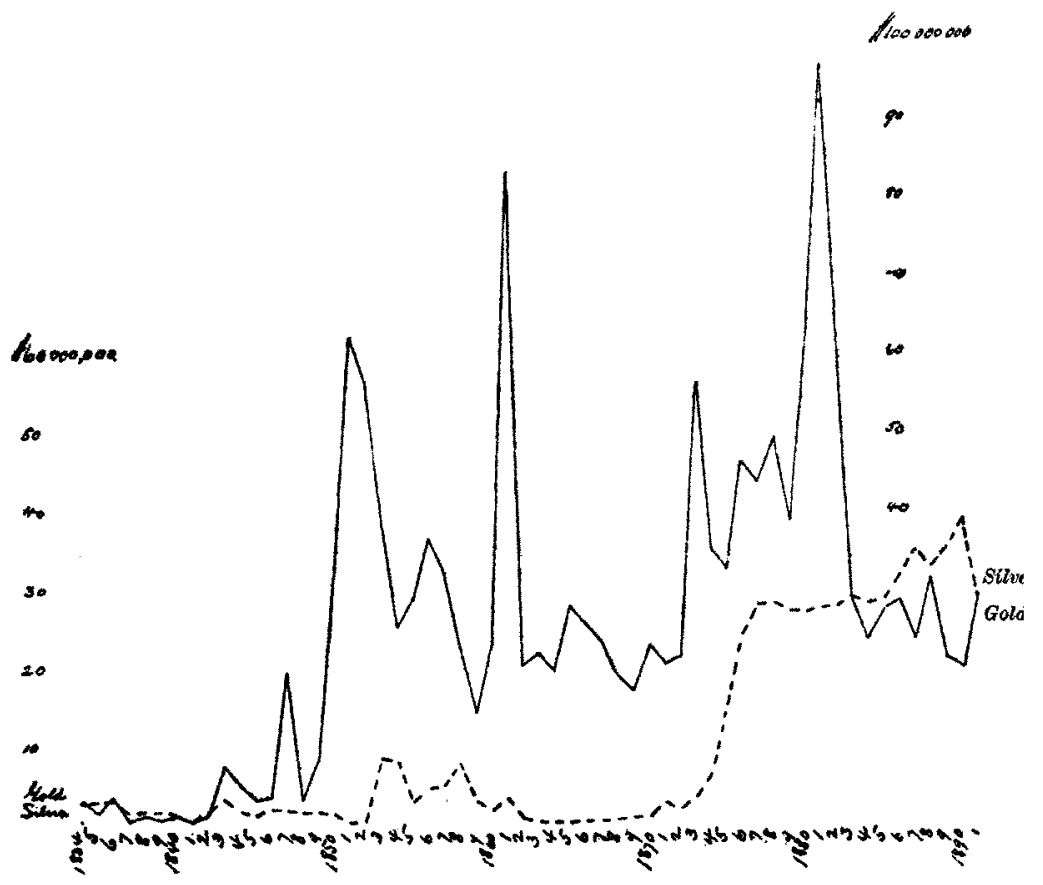


Diagram II. - Coining Value of the Gold and Silver Produced from the Mines of the United States (I853-r89I).

$275,000,000$

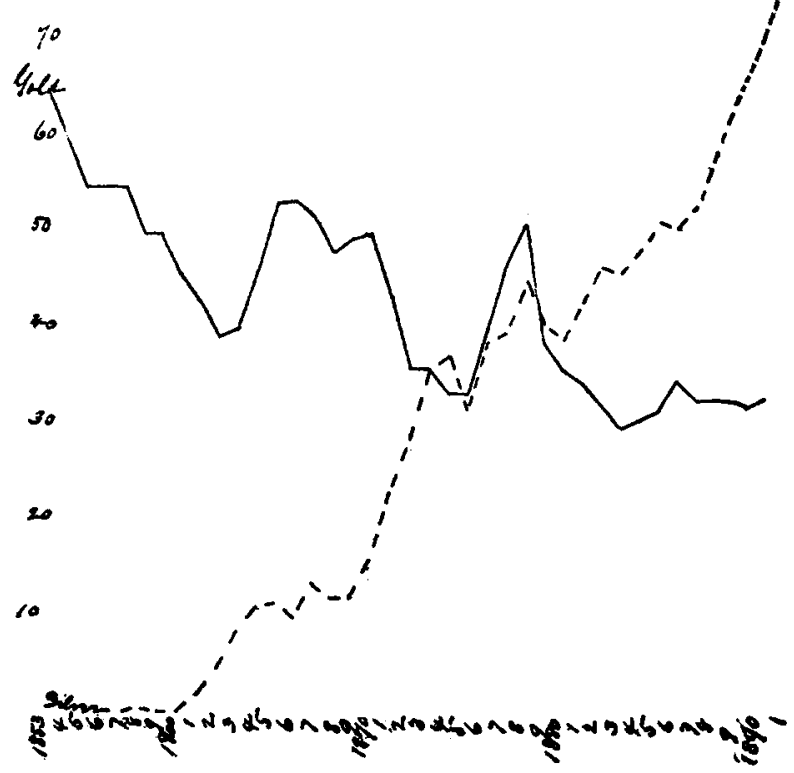


Use of Silver in the United States.

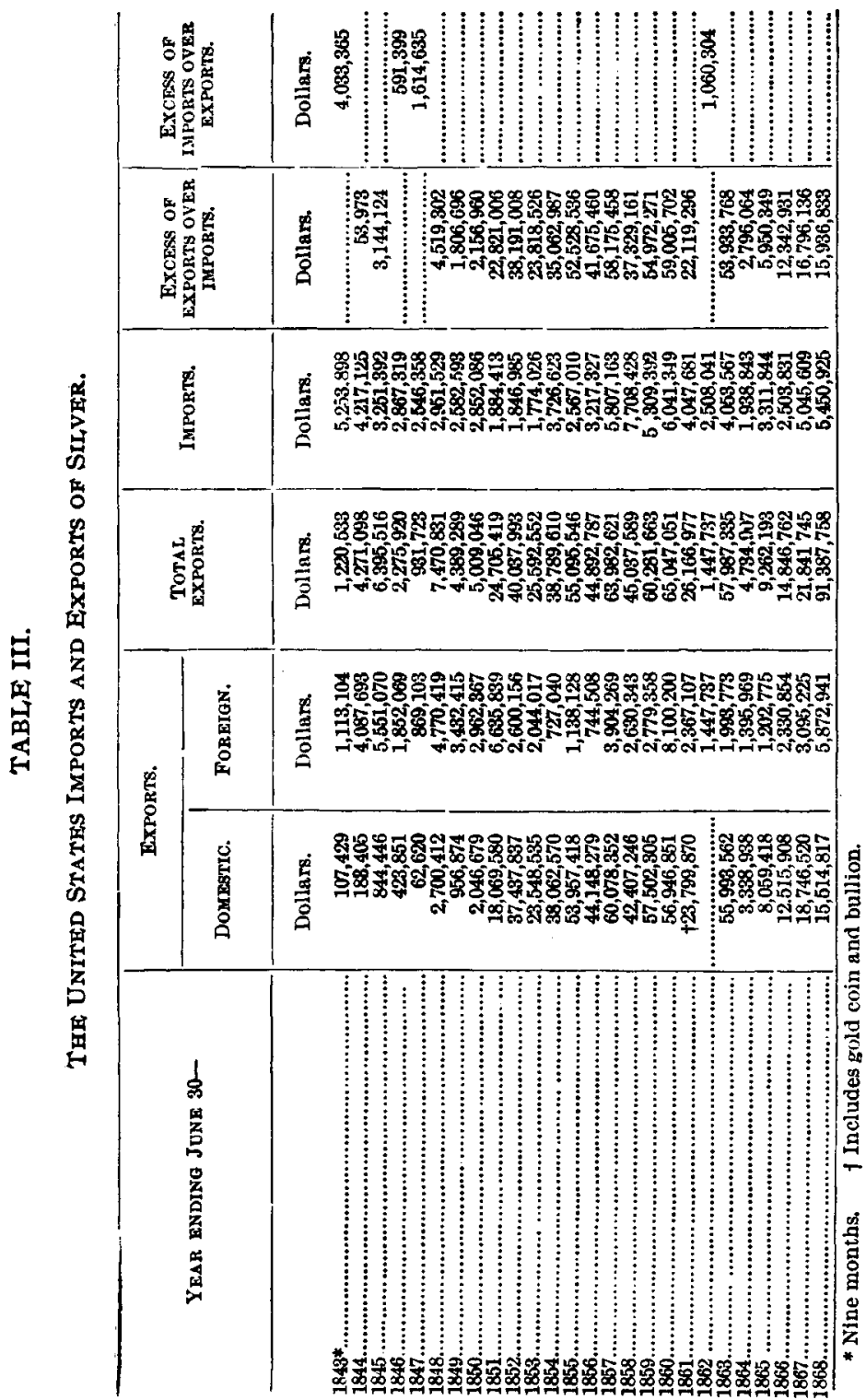




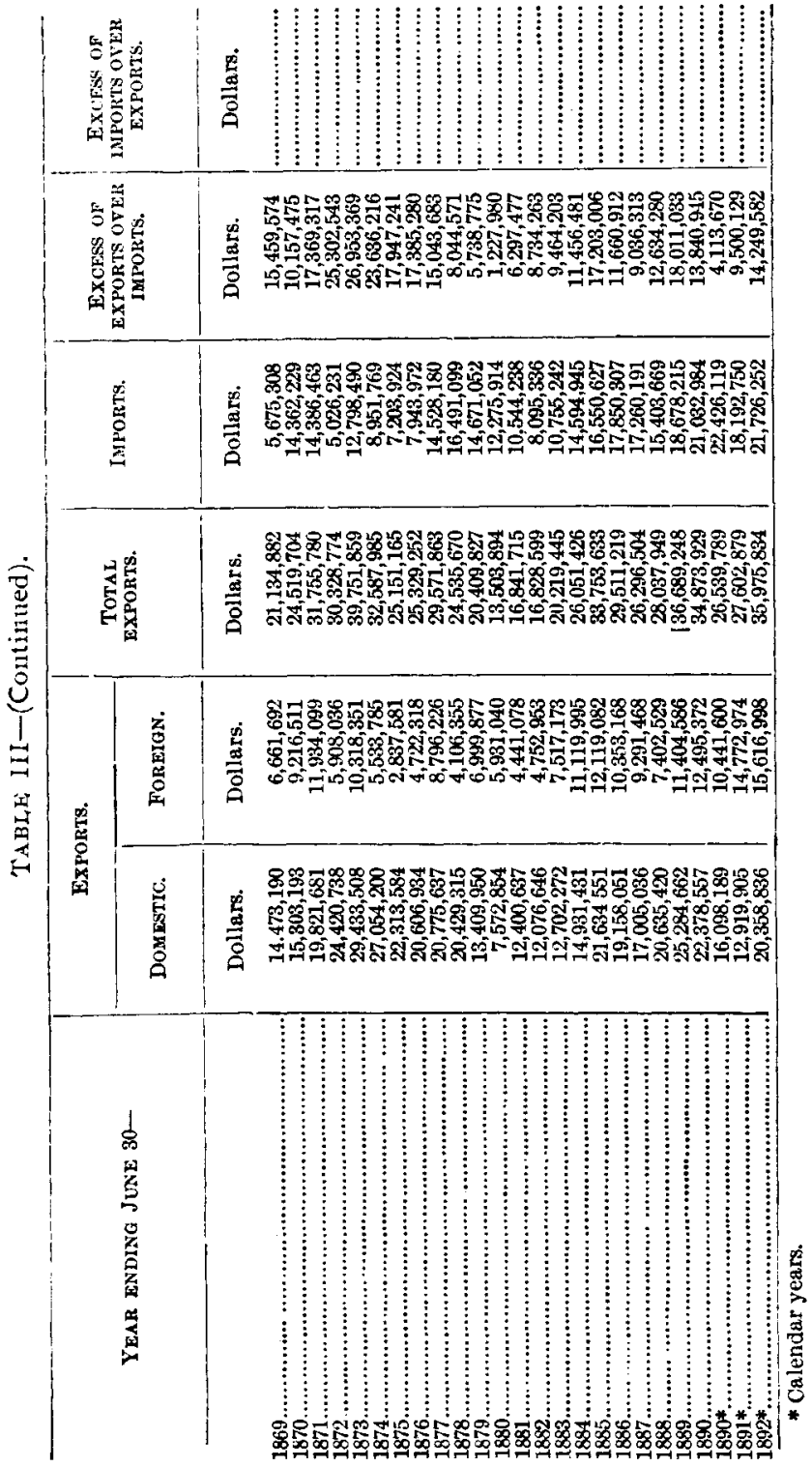


USE OF SILVER IN THE UNITED STATES.

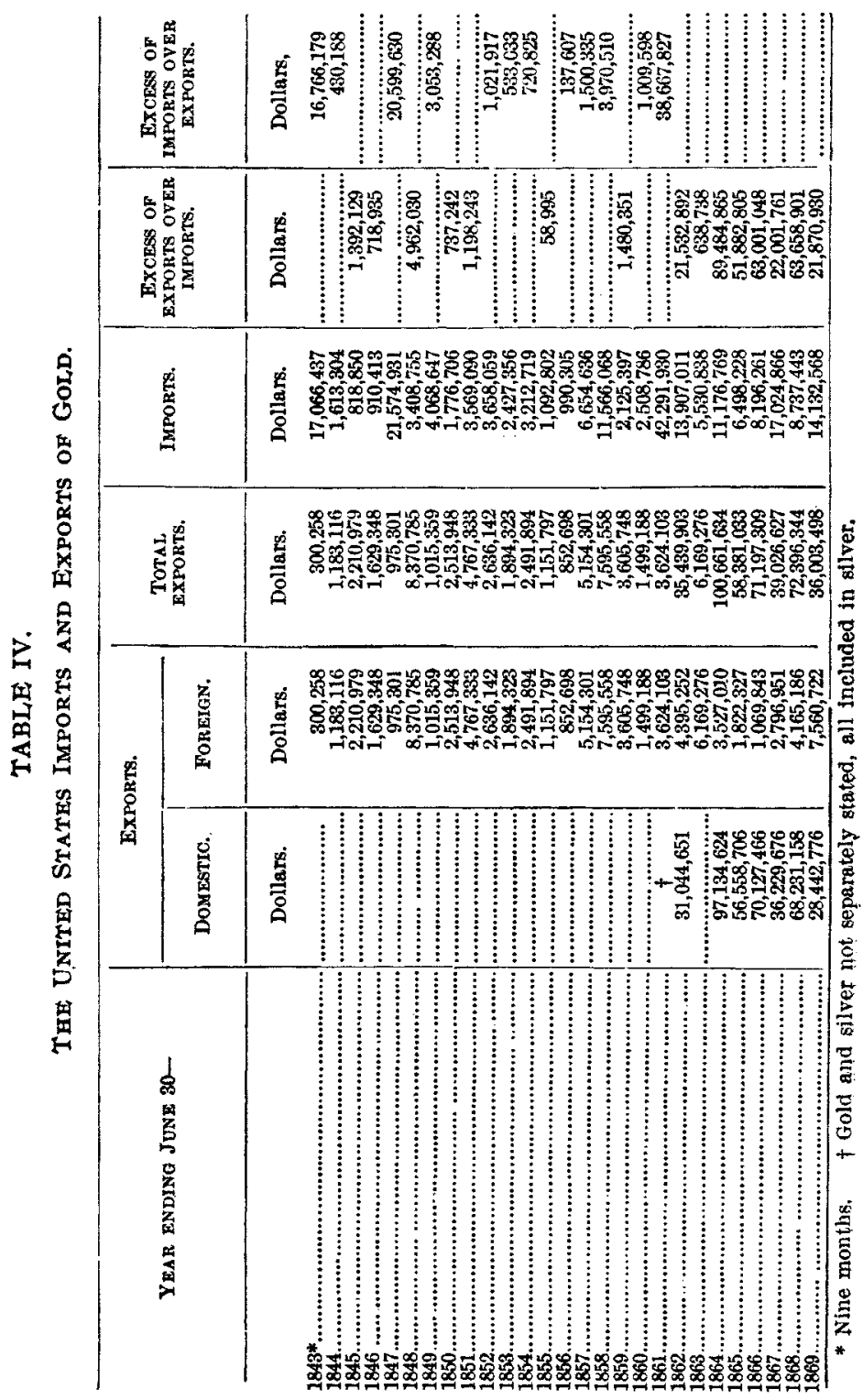




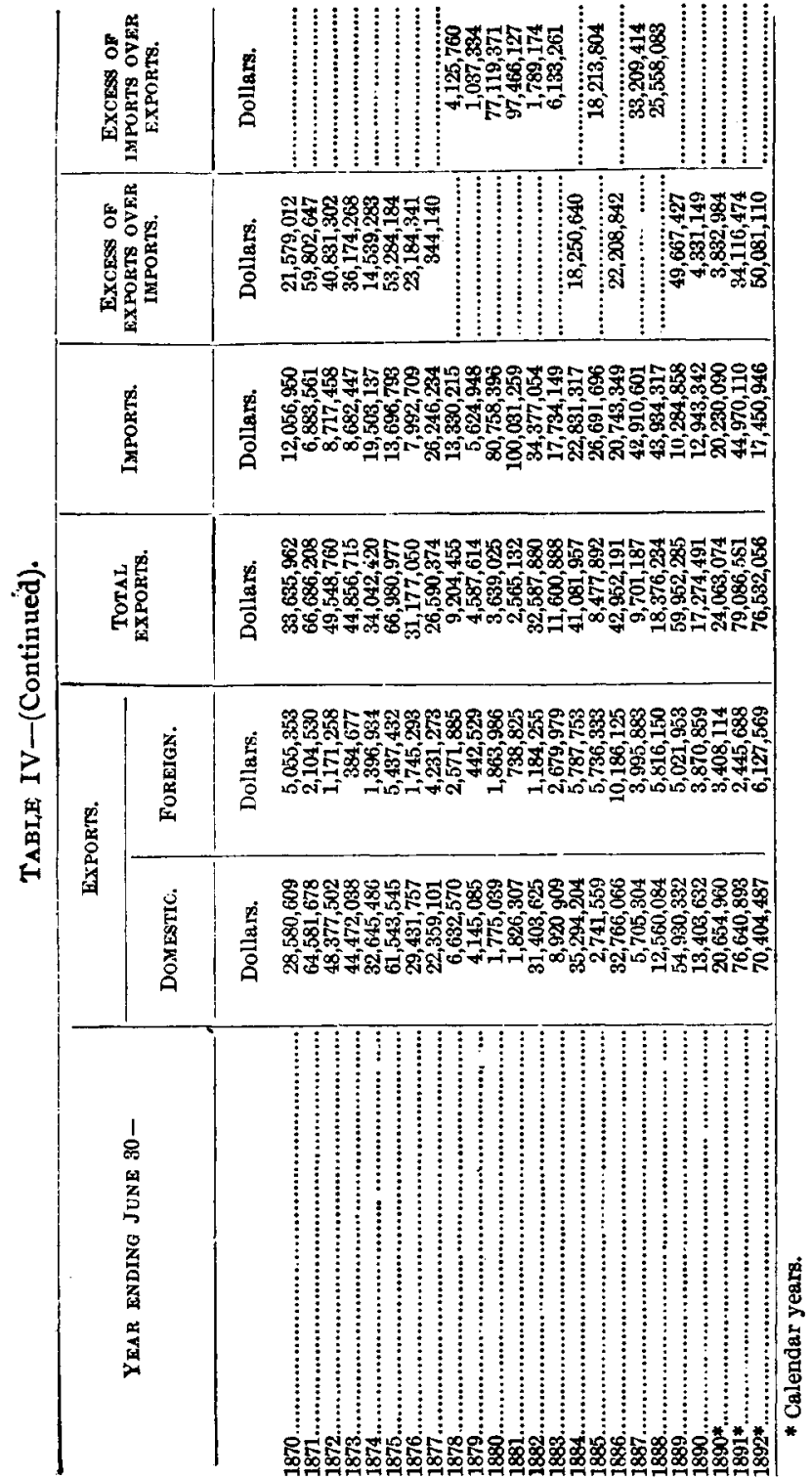




\section{TABLE V.}

Average annual, Productron of Gold and Silver in the WORLD BY PERIODS FROM 1492 to 1880.

From Soetbeer, as quoted in Laughlin's "History of Bimetallism in the United States," pp. 217-219.

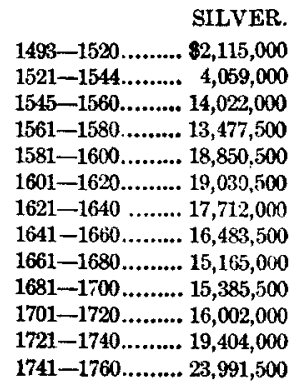

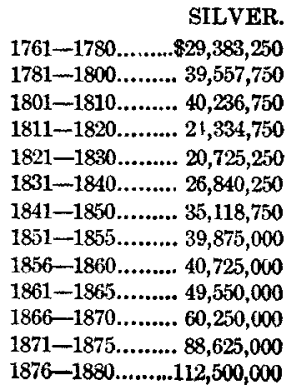

GOLD.

$\$ 14,441,750$

$12,408,500$

$12,400,000$

$7,983,000$

$9,915,750$

$14,151,500$

$38,194,250$

$137,775,000$

$143,725,000$

$129,125,000$

$133,850,000$

$119,050,000$

$119,975,000$ 
Diagram III.-Annual Production of Gold and Silver in the World (coining value), for the calendar years $1873-1891$.

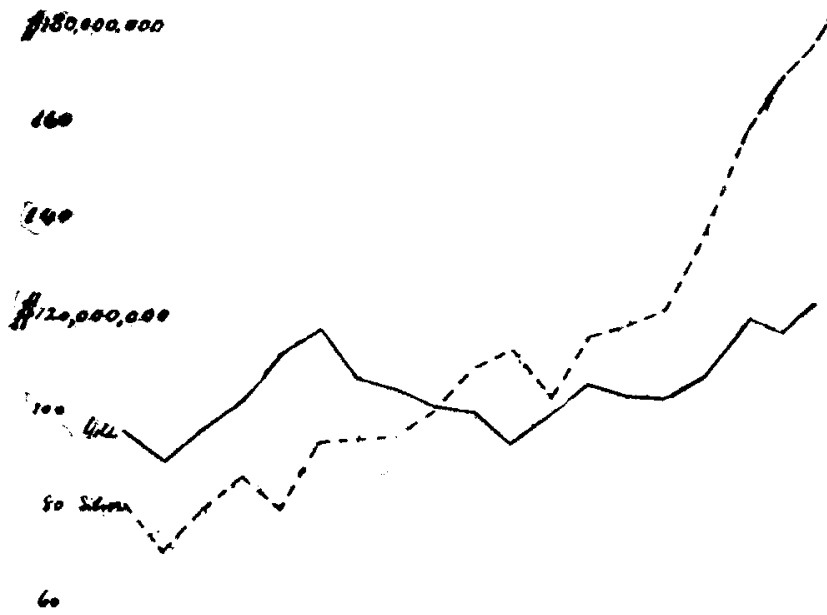

10

10

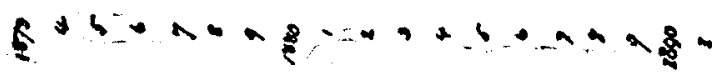




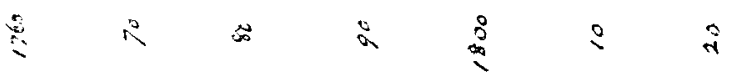

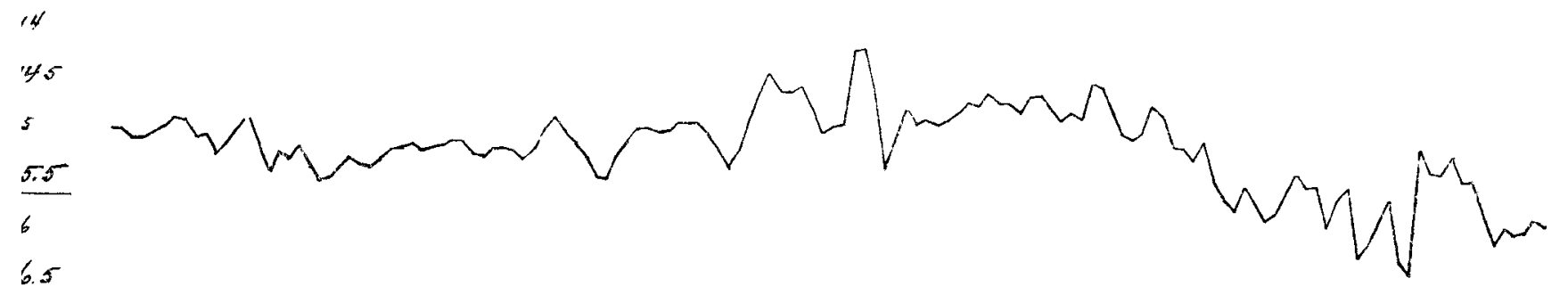




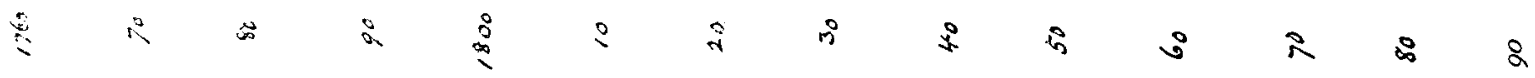
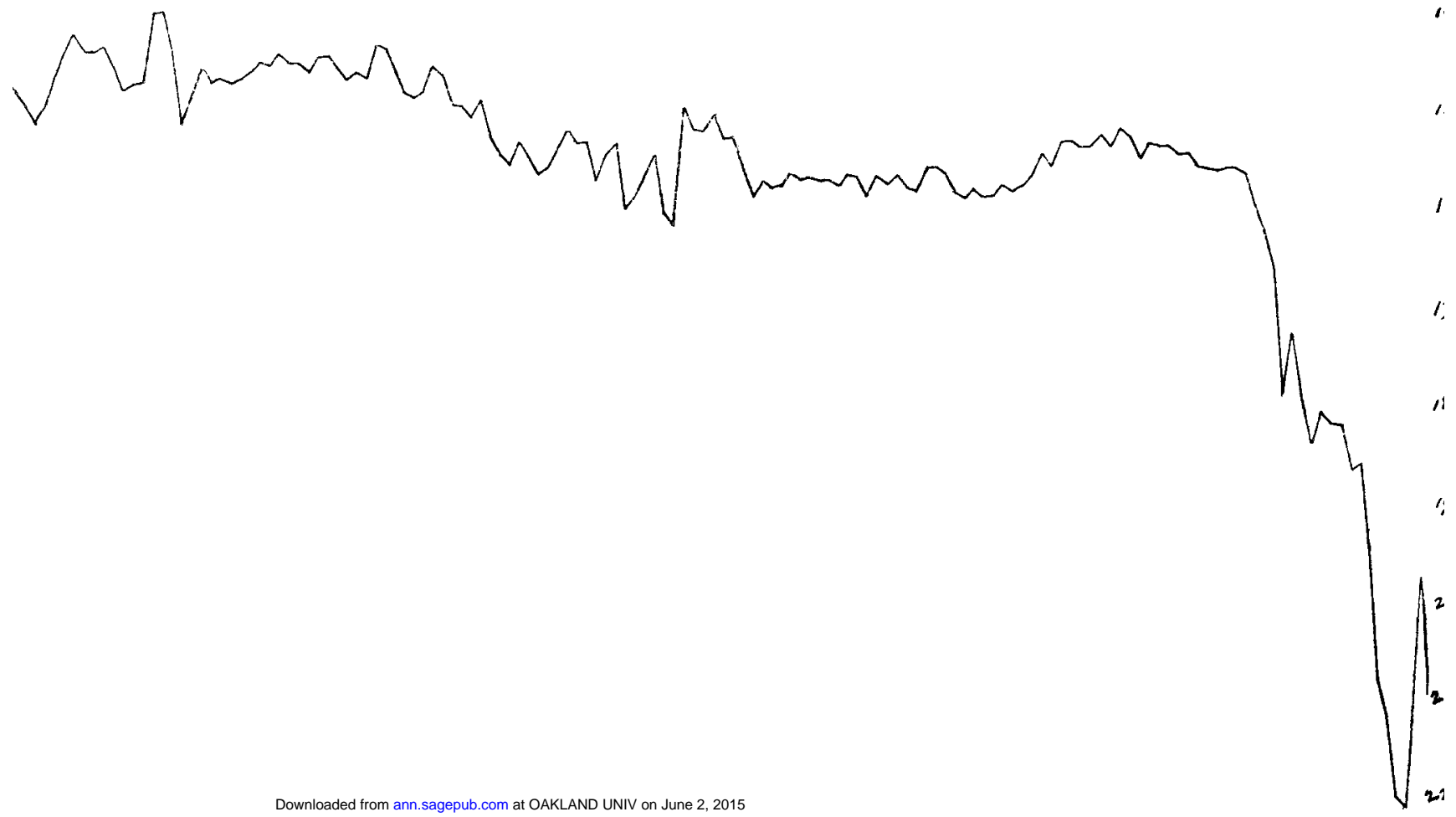


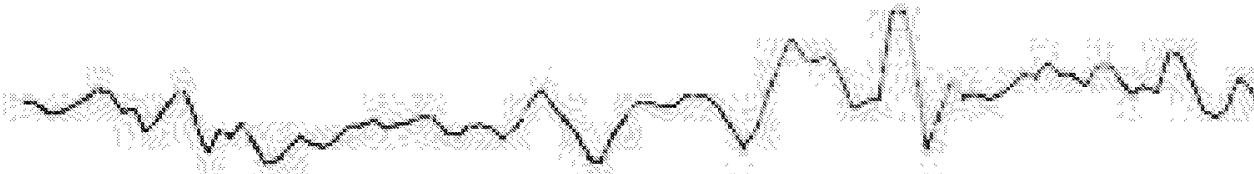

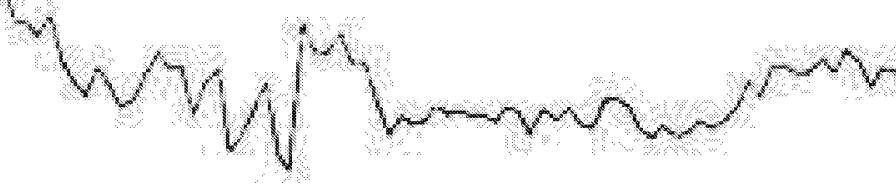


Diagram V.-Value of an Ounce of fine Silver at average quotation ( $1833-1892)$.

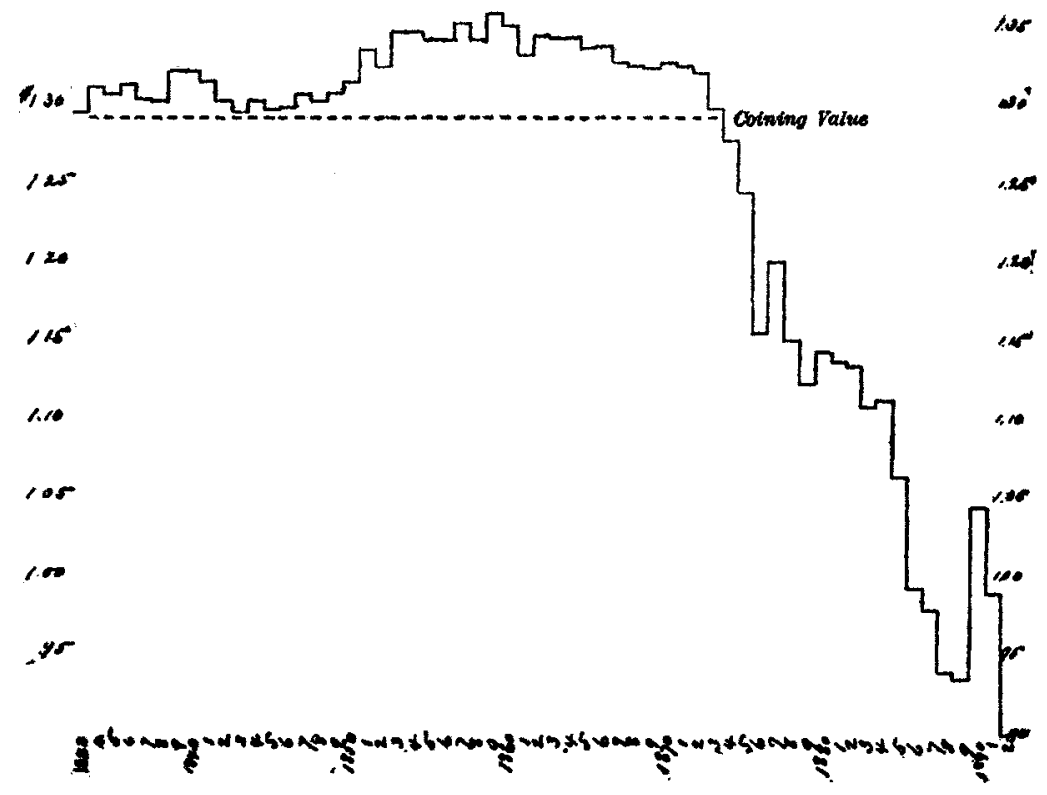

